


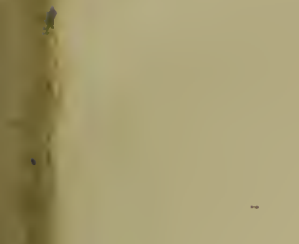

$=$

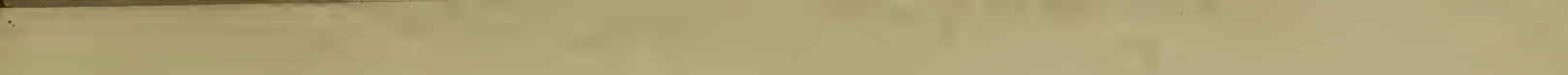




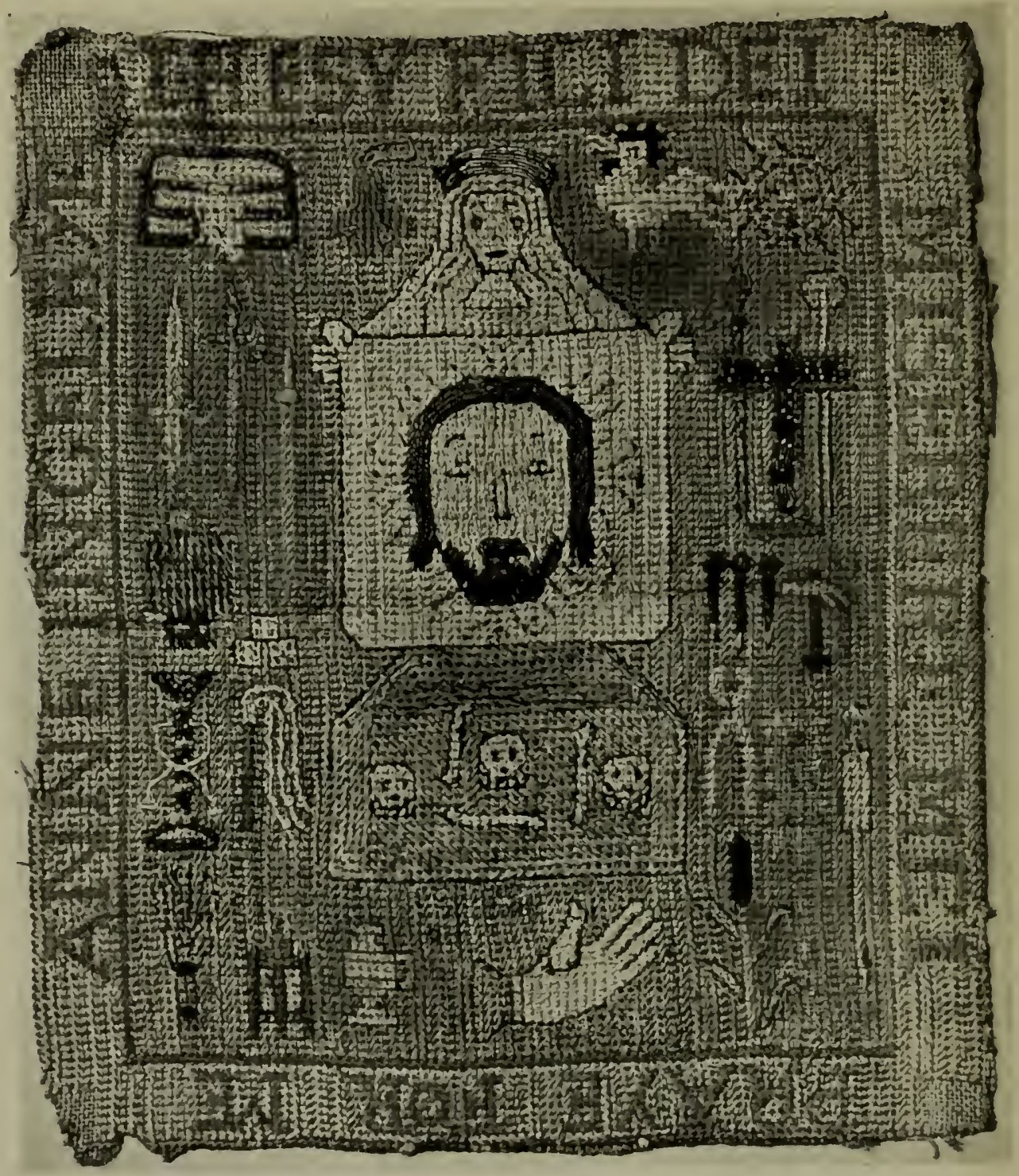

12. ENGLISH ; late I6th or early I7th century. (p. II.) 
CHM.VICTORIA AND ALBERT MUSEUM DEPARTMENT OF TEXTILES

\title{
CATALOGUE OF SAMPLERS
}

\author{
WITH I6 ILLUSTRATIONS.
}

LONDON: PRINTED UNDER THE AUTHORITY OF HIS MAJESTY'S STATIONERY OFFICE, I922. 


\section{Publication No. II 5 T.}

Crown Copyright Reserved.

First printed, September 1906.

Second Edition, November 1915.

Third Edition, February 1922.

This Catalogue may be obtained directly from the Victoria and Albert Museum, price 1s. 6d. net. (by post 1s. Sd.) It may also be obtained either through any bookseller or directly from H.M. Stationery Office at the following addresses: Imperial House, Kingsway, London (W.C.2), and 28, Abingdon Street (S.W.I); 37, Peter Street, Manchester; I, St. Andrew's Crescent, Cardiff; 23, Forth Street, Edinburgh; and Eason \& Son, Ltd., 40 and 4I, Lower Sackville Street, Dublin.

ii

(4568) Wt. $19624 / 733 \quad 12 / 21 \quad 1500$ Harrow G.57 


\title{
NOTE TO SECOND EDITION.
}

\begin{abstract}
LIST of the Museum collection of samplers issued $A$ in Igo6 being out of print, advantage has been taken of the opportunity thus afforded of rearranging it so as to bring it more into conformity with the recent publications of the Museum, and of including samplers acquired since that year. This work has been entrusted to Mr. P. G. Trendell, Assistant-Keeper of the Department. The samplers in the circulation collections of the Museum are not included in this catalogue.
\end{abstract}

Department of Textiles,

A. F. KENDRICK. November, I9I5.

\section{NOTE TO THIRD EDITION.}

GINCE the publication of the second edition the $\checkmark$ number of samplers in the Museum collection has about doubled. A great part of this increase is due to important accessions of Spanish and Italian samplers, which have been procured and contributed by donors with the express object of strengthening the collection in examples from these countries.
Department of Textiles,
A. F. KENDRICK.
December, I92I. 



\section{TABLE OF CONTENTS.}

INTRODUCTION $\ldots \ldots \ldots$ PAGE

$\begin{array}{llllllll}\text { I. ENGLISH } & \ldots & \ldots & \ldots & \ldots & \ldots & \ldots & 7\end{array}$

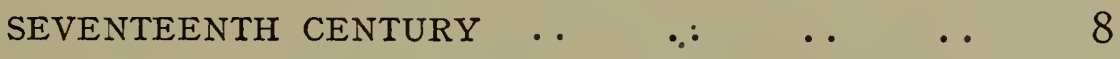

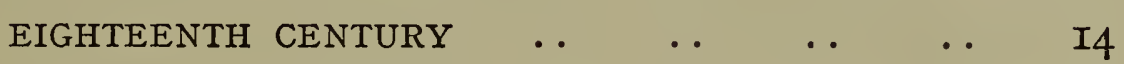

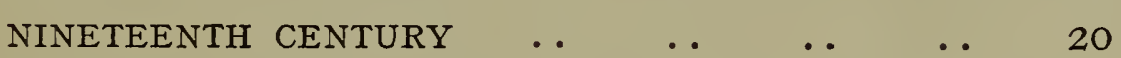

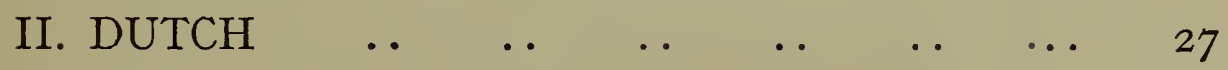

$\begin{array}{llllllll}\text { III. FRENCH } & \ldots & \ldots & \ldots & \ldots & \ldots & \ldots & 28\end{array}$

$\begin{array}{llllllll}\text { IV. GERMAN } & \ldots & \ldots & \ldots & \ldots & \ldots & \ldots & 30\end{array}$

$\begin{array}{llllllll}\text { V. ITALIAN } & \ldots & \ldots & \ldots & \ldots & \ldots & \ldots & 34\end{array}$

$\begin{array}{llllllll}\text { VI. SPANISH } & \ldots & \ldots & \ldots & \ldots & \ldots & \ldots & 37\end{array}$

$\begin{array}{lllllll}\text { VII. SCANDINAVIAN } & \ldots & \ldots & \ldots & \ldots & \ldots & 53\end{array}$

LIST OF USEFUL WORKS ON SAMPLERS IN THE LIBRARY OF THE MUSEUM $\begin{array}{llllll}\text { NUMERICAL INDEXES } & \ldots & \ldots & \ldots & \ldots & 56\end{array}$ $\begin{array}{lllllll}\text { GENERAL INDEX } & \ldots & \ldots & \ldots & \ldots & \ldots & 60\end{array}$ 


\section{LIST OF ILLUSTRATIONS.}

Frontispiece - I2. English; late I6th or early I7th century (p. II).

PLATE I.-I3. English; first half of I7th century (p. II).

., II $-I$ and II. English; dated $I 643$ and I6g6 (pp. 8, IO).

, III.-6. English ; dated I66r (p. 9).

"IV.-2I. English; second half of I7th century (p. I4).

". V.-20 and 27. English; second half of I7th century, and dated I73I (pp. I3, I5).

" VI.-49. English; dated I826 (p. 22).

: VII.-62. Dutch; dated I798 (p. 27).

,, VIII.-66. German; dated I68I (p. 30).

"IX.-69. German; dated I807 (p. 3I).

"X. $\left\{\begin{array}{c}\text { 37. English or Dutch; dated I799 (p. I9). } \\ 78 . \text { From Florence; late I8th or early Igth } \\ \text { century (p. 35). }\end{array}\right.$

, XI.-8I. Spanish; dated I756 (p. 37).

", XII.-77. Italian; I7th century (p. 35). 


\section{CATALOGUE OF SAMPLERS}

INTRODUCTION.

THE term Sampler is derived from the Latin word "exemplar," meaning a pattern, and it is found spelt in various ways such as "saumplarie, sawmplar, sampleth, and sam-cloth." It was first confined to a record, probably worked by adults, of patterns both in embroidery and lace. Subsequently it denotes an exercise in needlework done by children, often of tender age, to show the degree of skill they had attained, and to teach them the letters of the alphabet, the numerals, texts from the Bible, moral maxims, poetry, geography, etc. Nos. 6, II, I3, I4, I7, and 2 I are specimens of the former class, and Nos. 9, 27, 32, 34, 5I, and 54, of the latter.

REFERENCES to samplers are found in English literature from the I6th century onwards. One of the earliest instances occurs in the following lines written by the Poet Laureate, John Skelton (about I460-I529) :-

"With that the tappettis and carpettis were layd, Whereon theis ladys softly myght rest,

The saumpler to sow on, the lacis to enbraid." 1

Sir Philip Sidney laments in his "Arcadia" (about I576. II, II9) "Alas then, o Loue, why doost thou in thy beautifull sampler sette such a worke for my Desire to take out, which is as much impossible?" Thomas Kyd in The Tragedie of Solimon and Perseda (I599. I, ii) asks: "When didst thou, with thy sampler . . . sit sowing?" Shakespeare makes mention of samplers in two well-known passages. In Titus Andronicus (Act II, scene 5) Marcus states:

" Fair Philomel, she but lost her tongue,

And in a tedious sampler sew'd her mind ; " whilst in A Midsummer Night's Dream (Act III, scene 2), Helen speaks :

"We, Hermia, like two artificial gods,

Have with our needles, created both a flower, Both on one sampler, sitting on one cushion."

(1) Gavlande of Laurell, I523. Vol. I., 11. 787-9. 
Herrick also has the invitation in the Hesperides ("The Wounded Heart") :

"Come bring your sampler, and with Art, Draw in't a wounded Heart."

Thomas Milles, in The Treasure of auncient and moderne Times (I6I3. I, 762), writes :-

"Feare God, and learne womens huswiuery;

Not idle Samplery or silken follies ;" and William Hawkins in Apollo Shroving (I627. Prol., 5), gives the further advice: "Take out thy fescue, ${ }^{1}$ and spell here, in this one-leau'd booke. Tell the stitches in this sampler of blacke and white "- perhaps referring to Elizabethan or early Jacobean "black work" embroidery. On the other hand Jasper Mayne's lines in The Citye Match (I639. II,ii), may allude to the texts upon samplers or the Scriptural pictures of the I7th century; they run:

"Your school-mistresse . . . teaches

To knit in Chaldee, and worke Hebrew samplers." Milton in Comus $^{2}$ makes the following allusion:

"Coarse complexions,

And cheeks of sorry grain, will serve to ply

The sampler, and to teaze the huswife's wool."

Thomas Brooks in A Golden Key ${ }^{3}$ records "Such as begin to work with the needle, look much on their sampler and pattern," and Dr. Johnson in the Idler ${ }^{4}$ adds significantly " Our girls forsake their samplers to teach kingdoms wisdom." Other references can be traced in the writings of Keats, Pope, Burns, Thackeray, Dickens, Calverley, and Miss Mitford (Our Village).

Notices also occur in documents and historical manuscripts of the I6th century. For example, the household accounts of Queen Elizabeth of York (I465I503), preserved in the Public Record Office, contain the entry: "To Thomas Fissch, for an elne, of lynnyn cloth for a sampler for the Quene, viijd." Further, in an inventory of King Edward VI's property, made in I552, occur the following references: "Item, xii samplars" ; "Item, one samplar of Normandie canvas, wrought with green and black silk"; "A book of

(1) A pointer of straw or wire used in teaching children to read.

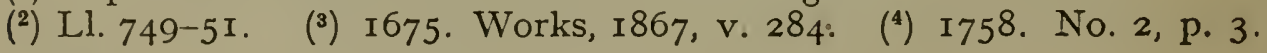


parchment containing diverses patternes."' 1 The will of Margaret Tomson, of Freston in Holland, Lincolnshire, proved at Boston, May 25th, I546, is another noteworthy instance. It contains the clause: "I gyve to Alys Pynchebeck my sawmpler with semes."2 Actual samplers before the I 7 th century are extremely rare, ${ }^{3}$ but subsequently they are comparatively numerous.

Samplers are found throughout Great Britain, and also in France, Belgium, Holland, Denmark, Sweden, Germany, Switzerland, Italy, Spain, and America. Specimens worked in Mission Schools as far east as Calcutta are known. On some English, Scotch, and American samplers the town and school are recorded.

THE Museum collection of English samplers runs in a fairly complete sequence from the first half of the I7th to the second quarter of the Igth century. The earliest dated specimen (No. I, Plate II) belongs to the year I643 but two others, with patterns resembling the close stitchery of I7th century purses (Nos. I3 and I4), were probably worked during the first half of the same century ; they are, unfortunately, not dated (Plate I). One of the most recent samplers is dated I842 (No. 53).

There are now two Scandinavian samplers in the Museum (Nos. I38 and I39), the former dated I863 from Ska, Sweden, and the latter with date I798 from Copenhagen. An embroidered panel from Denmark, recently acquired (No. 59-I9I4), has numerous squares worked with small patterns arranged round the central compartment, representing Christ and the woman of Samaria. These may have been intended to serve the same purpose as a sampler. The panel is dated I75I.

In the I7th century the small detached floral patterns and the graceful repeating borders (the latter showing the influence of contemporary Italian embroideries) resemble the needlework decoration upon Elizabethan articles of

${ }^{(1)}$ Mrs. Palliser's History of Lace, I902 edition, foot-notes to p. 9.

(2) Essex Review, I908, xvii., I47.

(3) The London Museum possesses a sampler with horizontal bands of lace-work. In one of them is shown the Royal Arms of England, with the initials E.R., apparently referring to Queen Elizabeth. An important embroidered panel in the Victoria and Albert Museum (8r6-1893) is worked with the Royal Arms of the United Kingdom, the initials I.R. for James I, and a symmetrical tree bearing flowers and grapes on each side. The name of the embroideress, "MARY HVLTON," is in the bottom corners. 
costume-such as tunics, shirts and headdresses, purses and coverlets. ${ }^{1}$ The alphabets and numerals worked upon the majority of the I8th and Igth century samplers were doubtless a practice for the working of household linen.

The various patterns were derived partly from pattern books, of which the best known was published in England in I632, A Schole House for the Needle, by Richard Shorleyker. The Venetian pattern books ${ }^{2}$ of the later part of the I6th and the early I 7 th centuries were largely used for the geometrical devices of the drawn and cut work bands. As the pattern books published in different countries often copied each other, a certain conservative tendency is apparent in the designs worked on the samplers.

The favourite patterns in the I 7 th century were mostly floral and geometric in character, the flowers, especially on English samplers, representing well-known varieties, such as red and white roses, carnations, tulips, pansies, and honeysuckle; acorns and strawberries are also shown. Occasionally small quaint human figures are introduced (Nos. 8, 23, and 26), bearing flowers or other devices, to which the name of "boxers" has been given. In the I 8 th and Igth centuries more pictorial patterns occur-Adam and Eve in the Garden of Eden, landscapes, small formal houses within fenced enclosures, fruit trees, flowering plants in pots, birds and animals. The numerals and alphabets were supplemented by religious verses, sometimes of a strangely melancholy character, together with moral maxims and texts from the Scriptures. This change was probably due to the rise of Methodism ${ }^{3}$ during the first half of the I8th century. " "Epistle" samplers

(1) See examples in the Museum collection.

(2) See Ostaus, La Vera Perfettione del Disegno, I56r. Parasole, Pretiosa Gemma delle virtuose donne, I6oo. Vecellio, Corona delle nobili et virtuose donne, I593. Vinciolo, I singolari e nuovi Disegni, I606.

(3) Wesley's hymns were first published in 1736.

(4) An interesting application of the idea of the sampler to purposes of utility can be seen on an apron of drawn and embroidered muslin in the Museum (I564-1904). In addition to a wavy stem pattern with fantastic birds, it has four texts, mainly from the Proverbs of Solomon, and the inscription " MARY TYKELL IN THE I 4 YEAR OF HER AGE, I7I7." Another example, corresponding with samplers of the second half of the I8th century, is a linen Hold-all and Needle-case (I-I903) embroidered, with silks in cross-stitch, with ten verses of religious character, surrounded by flowering plants in vases, baskets of fruit, and butterflies. 
in the form of short letters are occasionally found during the I8th century, ${ }^{1}$ and about I780 map samplers were popular. The latter were probably suggested by the new interest in travel and colonisation. Figures represented in contemporary costume appear during the reign of George III, and there is a quaint figure of a soldier or pensioner, inscribed "My dear father," on a sampler in the Museum (No. 56). The name of the embroidress, with the date of the completion of the work, is commonly found on English samplers.

Foreign samplers seldom possess any pictorial character, texts and verses are usually absent, and the record of the worker's age has not often been found. On some Spanish specimens, the teacher's name is also recorded (Nos. 83, 84, 92, I05, II6, and I25).

English samplers of the I7th century were worked on long strips of bleached or unbleached linen, sometimes about a yard long. In the early part of the I8th century they were shorter, and they soon became nearly square. The linen was then of a yellower colour and more harsh in texture. Towards the close of the century a woollen tammy cloth or " sampler canvas" was introduced, which has often suffered subsequently from the attacks of moth. About I8oo, quite small samplers were popular (No. 33). The fabric of the darned samplers, which then made their appearance, was a kind of transparent gauze, stiffened with gum, known as tiffany. In the early part of the Igth century coarse linen and linen canvas were again used. A few oval $^{2}$ and heart-shaped ${ }^{3}$ samplers are found, but the majority are either oblong or square. Foreign samplers are usually of linen.

Both Danish and Swedish samplers are met with of white muslin, with patterns of stitches for the "Tönder" drawn work, which was much used in the I8th and early Igth centuries on fichus, collars, and other articles of costume (No. I38). One Museum specimen (No. 72), probably from North Germany, bears

(') See Tuer, History of the Horn Book, Vol. II, cut 202, dated 1778.

(2) See Tuer, History of the Horn Book, cut I96, dated i8o9.

(3) See Huish, Samplers and Tapestry Embroideries, fig. 23, dated I796. 
resemblance to this class, and another is from the province of Uppland, Sweden (No. I38).

The embroidery is usually done in coloured silks, with the rare addition of metal threads; linen thread is, however, used for the "white work" on I7thcentury samplers, and, at a later period, both cotton and woollen threads are employed. In the last quarter of the I7th century some details are found semidetached or raised by padding in the style of the grotesque contemporary " stump-work" upon caskets and pictures (Nos. 9 and II). The openwork upon I7th-century samplers consists of cut and drawn work, with needlepoint lace fillings in the style of the Italian reticella. A flat satin stitch was common at the same time, and, when worked in white thread, it is known as damask stitch. Short and back stitches were also used, and French knots and petit point were occasionally introduced.

The lettering both in the I7th and I8th century is embroidered in cross, satin, and bird's-eye or eyelet stitches. Darning stitches were popular in various diaper patterns at the close of the I8th century; they were either worked over the fabric or across squares previously cut out of the ground (Plate X); both back and front are often alike (Nos. 37, 42, and 6r). In the Igth century cross stitch was so general that it received the name of sampler stitch.

In foreign samplers the embroidery is usually done with coloured silks, sometimes in bright colours. The Spanish specimens have a considerable variety of stitches, as well as occasional decoration in drawn work. Both in German and Dutch samplers darning stitches occur.

It is evident that England was the chief producer of samplers, and the practice of working them continued general until about the middle of the Igth century. After a long, unbroken tradition of nearly 300 years, it would be a source of regret if this charming and domestic branch of needlework, with its special individual record, should so far wane in popularity as to become extinct. 


\section{ENGLISH.}

THE decoration of I7th-century samplers is in the form of horizontal bands of varying width, filled with repeating floral and geometrical patterns frequently in the style of the graceful Italian borders of the period (No. I7). One example, dated I66r (No. 6), has an interesting copy of lace scallops in embroidery (Plate III), and another worthy of notice (No. 20) has a very decorative alphabet worked in needlepoint lace (Plate V).

The colours of the embroidery silks were somewhat brighter in the early part of the I8th century than in the preceding century, reds, blues and greens in more vivid tones being frequently used. At this time also considerable care was taken with the lettering, and borders of repeating wavy or angular design were first introduced. A sampler dated I7Io (No. 24), which is still divided into horizontal bands, is worked at the bottom with a representation of the blue and white earthenware popular at that period, and another, dated I73I (No. 27), bears upon it the complete Apostles' Creed and the Lord's Prayer (Plate V). The patterns as the century advanced became more scattered. The map samplers, referred to in the Introduction (p. 5), were produced approximately between I770 and I8Io ; the single one exhibited (No. 35) is dated I792.

In the early part of the Igth century the patterns became still more disjointed. Alphabets were frequently large and clumsy, and crowns and coronets are seen. Some tasteful designs survived (Plate VI), however, until a late period (No. 49, dated I826), but the sampler steadily deteriorated, and it gradually disappeared about the middle of the Igth century.

The earliest dated sampler in the Museum collection which records the name of the worker is that done by " Rebeckah Pope " in the year I644 (No. 2); and the first statement of the child-worker's age is No. 9, the inscription on which runs: "Margreet Lucuh (Lucus?), I68r. Being ten Year old come July the First." The youngest workers recorded are "Catherine Pickling . . aged 7 years, I 780 " (No. 3I), and "Harriot Taylor, Ag'd 7 " (No. 54). On no sampler in the following list is found the name of the school or locality where it was worked.

The small panel (No. I2) of late I6th or early I7th-century date recently presented by Mr. F. Leverton Harris, M.P., is included in this catalogue, although perhaps it should not strictly be called a sampler. It is worked with the Emblems 
of the Passion, a brief supplication, and the name of the embroidress, "Anne Ingelbye." (Frontispiece.)

Samplers are represented in Francis Wheatley's picture of "The Schoolmistress," and in George Morland's "Visit to the Boarding School," the latter in the Wallace Collection.

The earlier specimens possess a rare charm, both in their decorative patterns and harmonious colouring, and well repay careful study.

\section{SEVENTEENTH CENTURY.}

(I) Dated.

I. Linen, embroidered with coloured silks and white linen thread partly in satin and cross stitches; it is also decorated with cut and drawn work filled with needlepoint stitches. At the top are seven horizontal bands of varying width, containing wavy stems bearing roses, honeysuckle and other flowers, acorns, fruit and S-forms, the letters of the alphabet, and the date "ANO DO I643," all worked in colours. Below are fourteen bands containing geometrical and floral patterns, including lozenges and zig-zag stripes, five being worked in white linen thread, and the remaining nine in cut and drawn work.

PLATE II.

L. $3 \mathrm{ft} .3 \frac{3}{4}$ in., W. $7 \frac{1}{2}$ in. Acquired in 1902 . Reproduced, Kendrick, English Embroidery, Plate LII.

Neg. No. 26I 46 .

2. Linen, embroidered with coloured silks and white linen thread partly in knotted and cross stitches. Four horizontal bands of varying width filled with repeating conventional rose-trees and lilies, also acorns, worked in coloured silks alternating with five bands containing geometrical patterns of lozenges, S-forms and zig-zag stripes in white linen thread. Below the second band are the name and date: "REBECKAH POPE, I644," with the letters of the alphabet.

L. 2 ft. 2 in., W. 9 in. Acquired in 1908.

3. Unbleached linen, embroidered with coloured silks partly in cross and satin stitches. Six horizontal bands of gradually increasing width from top to bottom, filled with alternately reversed conventional floral ornament, consisting of wavy and interlacing stems bearing roses and other flowers. At the bottom is the alphabet in large and small letters, with the name " MARTHA SALTER, I65I," and the words, "The feare of God is an excellent gift."

L. 18 in., W. 9 in. Acquired in 1905.

Neg. No. 37627 . 
4. Unbleached linen, decorated with lacis or darned netting, and cut and drawn work filled with needlepoint lace stitches, and also embroidery in white linen thread. At the top are eleven horizontal bands of openwork of varying width, filled with repeating wavy floral stems, fleurs-de-lis, lozenges, octagons, stars, and other geometrical devices, together with two representations of a mermaid combing her hair. Below are ten bands chiefly worked in satin stitch with angular stems bearing carnations, detached blossoms within lozenges, and other devices. At the bottom are worked the letters of the alphabet, with the name "MARGREET MAY" and the date I654.

L. 2 ft. $5 \frac{1}{2}$ in., W. 9 in. Acquired in 1872 . Reproduced, Avt Workers' Quarterly, I4. Vol. IV., p. $73 . \quad$ Neg. No. 26I46.

5. Unbleached linen, embroidered with brightly coloured silks in cross, satin, and knotted stitches. Ten horizontal bands of varying width filled with angular stems (some interlaced) bearing roses, carnations, honeysuckle and other flowers, also grapes and acorns. At the top are geometrical devices, the inscription "MARY BVRROWES IS MY NAME," the letters of the alphabet, and the date 1656 .

L. 2 ft. $6 \frac{1}{2}$ in., W. $7 \frac{1}{2}$ in. Presented by Mrs. Miller in 1877 .

6. Linen, embroidered with coloured silks in various stitches, including cross and satin stitches. At the top are the letters of the alphabet, the initials MMV and the date I66r. Above is one horizontal band, and below are twenty-two others of gradually decreasing width, filled with detached stems bearing conventional roses, carnations and other flowers, also grapes, angular continuous stems with leaves and blossoms, and scalloped borders copied from contemporary lace edgings.

Plate III

L. $3 \mathrm{ft} . \frac{1}{4}$ in., W. II in. Acquired in 1907 .

Neg. No. 37635 .

7. Linen, decorated with cut and drawn work filled with needlepoint lace stitches, and embroidery in white linen thread. Six horizontal bands of varying width filled with rosettes, lozenges and other geometrical devices, and S-shaped scrolls. At the bottom are worked the letters of the alphabet, the date 1666 , and the name " ELIZABETH WOOD."

L. $5_{5}^{\frac{1}{4}}$ in., W. 8 in. Acquired in 1899 . 
8. Unbleached linen, embroidered with coloured silks partly in cross stitches. Twelve horizontal bands of varying width filled with angular leafy stems (some interlaced) bearing pansies, honeysuckle, carnations, and other flowers, together with strawberries, grapes, and acorns. In one band are two standing figures of men (boxers) holding flowers. At the top, amidst detached flowers, are the initials $\mathrm{I} \mathrm{H}$, and the date $\mathrm{I} 666$.

L. $2 \mathrm{ft} .3$ in., W. $7 \frac{1}{2}$ in. Acquired in 1899 .

Neg. No. 447 I 9.

9. Unbleached linen, embroidered with coloured silks and white linen thread partly in cross, chain, and satin stitches. There are also slight decorations in cut and drawn work, and some of the flowers are raised by padding and are covered with fine network. At the top, in colours, are two wide horizontal bands of floral devices within lozenges, and conventional flowering plants. In the middle, in white work, are two narrow borders and a broad band of geometrical ornaments (zig-zag stripes and rosettes), with small star-forms done in openwork with the needle. Below, in colours, are eight narrow borders, worked with the following inscription, the name and date, and also the letters of the alphabet, in various sizes :-

" MY FATHer Hitherto Hath done his Best To Make Me A workewoman Above the Rest Margreet, LvcvH [Lucus?] I68I. BeIng ten Year old come IULy THe First."

L. I 7 in., W. IO $\frac{1}{2}$ in. Presented by Miss A. L. Dixon in IgII.

Io. Loosely-woven linen, embroidered with coloured silks chiefly in cross stitch. Nine horizontal bands of varying width filled with angular leafy stems bearing roses, honeysuckle, and other flowers, and fruit, also fret ornament. At the top are the repeated letters of the alphabet, with the name "JANE HARRIS," and the date I694.

L. 20 in., W. 6 in. Acquired in 1899.

I I. Linen, embroidered with coloured silks and white linen thread partly in satin and cross stitches, with portions applied in relief, and also decorated with cut and drawn work filled with needlepoint stitches. Ten horizontal bands in colours, filled with wavy, interlaced, and angular stems bearing roses, honeysuckle, pansies, together with grapes, two bands with the repeated letters of the alphabet and the embroidress's name, five bands of geometric ornament in white work, and four bands of cut 
and drawn work filled with large and small rosettes within lozenges or squares, a zig-zag band, and plants. At the bottom are the letters of the alphabet, with the name " ELIZABETH MACKETT," and the date I696, also in white work.

Plate II.

L. 3 ft. $7 \frac{1}{2}$ in., W. $9 \frac{3}{4}$ in. Acquired in 1884 . Reproduced, Kendrick. English Embroidery, plate LIr., and Art Workers' Quarterly, I4. Vol. IV., p. 73 . Neg. Nos. 26r $46,29149,37626,37627$.

\section{(2) Undated.}

I2. Linen, embroidered with coloured silks chiefly in chain stitch, and silver-gilt thread. The middle contains a representation of St. Veronica holding the sacred napkin, with Golgotha below. The surrounding space is filled with the following Emblems of the Passion (beginning at the top left-hand corner) :- The tomb (?), purse, the cock, the crown of thorns, sword, axe and lance, spear, the cross, sponge on a reed, the coat and three dice, three nails and hammer, the pillar, a scourge, pincers and ladder, another scourge, lantern, vase of vinegar, a smiting hand, hyssop and a reed. All are worked in colours and gold on a pale green ground. There is a narrow border all round, with the following inscription in mauve (faded) on a yellow' ground: "IHESV FILI DEI MIISERERE MEI PRAYE FOR MIE ANNE INGELBYE."

Late I6th or early I7th century. Possibly the cover for a Book of Hours. FrontisPIECE.

L. $6 \frac{1}{2}$ in., IV. $5 \frac{5}{3}$ in. Given by F. Leverton Harris, Esq., M.P., in 1915. Neg. No. 39086.

I3. Loosely-woven linen, embroidered with silver-gilt and silver thread and coloured silks; some of the devices are partly in petit point and drawn work. (Unfinished.) Closely covered with a number of detached geometrical and floral patterns; among them are blossoms, rosettes, acorns, and S-forms within compartments; pansies, carnations, and strawberry plants, together with fish, birds, butterflies, caterpillars, and a toad. On one side are the letters "M.I." First half of 17 th century.

Plate I. I. I $19 \frac{1}{2}$ in., W. II $\frac{3}{4}$ in. Acquired in 1913.

Neg. No. 36177.

I4. Loosely-woven linen, embroidered with silver-gilt and silver thread and coloured silks; some of the patterns are in petit point and drawn work. Worked with twenty detached geometrical and floral patterns, including roses, carnations, blossoms, rosettes, swastikas, and S-forms within 
lozenge compartments, together with obelisks, acorns, and scale and interlaced ornament. First half of I7th century.

L. $17 \frac{1}{4}$ in., W. 9 in. Presented by Francis C. Eeles, Esq., in I9I8. No. I 3, Plate 1., is a closely similar specimen.

Some of the patterns in Nos. 13 and 14 resemble those found on contemporary English embroidered purses. A sampler of similar character is illustrated on Plate II. of Mr. Marcus Huish's Samplers and Tapestry Embroideries.

Neg. No. 48570.

I5. Unbleached linen, embroidcred partly in cross and satin stitches with coloured silks, and silver thread and spangles. Ten horizontal bands, varying in width, filled with angular and wavy stems delicately designed, bearing roses, pansies, honeysuckle and other flowers, and strawberries. Four small figures of men (boxers) in blue shirts and red breeches holding flowers (?) are introduced into one band, and the letters of the alphabet are worked along the top of the sampler, together with the initials "M.P." Middle of $I 7$ th century.

L. 2 ft. $\frac{1}{2}$ in., W. $7 \frac{5}{8}$ in. Acquired in rar 3.

I6. Unbleached linen, embroidered with white linen thread and red silk, and further decorated with drawn work filled in with needlepoint lace stitches. (Unfinished.) At the top are six bands of varying width in white work (oak stems with acorns, lozenges, and rosettes) and the words " Hannah Pittman Her-". Beneath is the incomplete inscription :"The Lamentation Of A Sinner. O Lord. Turn . not. Away. Thy . Face . From . Him That . Lies Prostret Lementing Sor His Sinful Life. Be-For . . Th" _- At the bottom are seven bands of floral and geometrical pattern, and S-forms, in openwork. The middle is plain. Middle of 17 th century.

L. $3 \mathrm{ft} . \mathrm{I}$ in., W. 6 in. Acquired in I9I3.

I7. Linen, embroidered with coloured silks partly in cross stitch (both sides worked alike). Eleven horizontal bands of varying width filled with zig-zag and wavy stems bearing honeysuckle, carnations, and other flowers, detached plants, lozenges, octagons, and geometrical ornament, and also the figure of an angel. At the top are small detached geometrical and floral devices. Second half of I 7 th century.

This specimen shows strong Italian influence.

L. $3 \mathrm{ft}$., W. 8 in., two pieces joined. Transferred from the Educational Division in 1877 .

Neg. Nos. 37639,37640 . 
I8. Linen, embroidered with coloured silks in cross, satin, and other stitches. Seven horizontal bands filled with a symmetrical pattern of angular stems (some interlaced) bearing pansies, roses (the petals semi-detached), honeysuckle, carnations, and other flowers, together with strawberries and acorns, and also S-forms. They are separated by the following lines in lettering of varying size :-

"When I was young I little thought

That wit must be so dearly bought

But now experience tells me how

If I would thrive then I must bow

And bend unto another's will

That I might learn both art and skill

To get my living with my hands

That so I might be free from band

And my own dame that I may be

And free from all such slavery.

Avoid vaine pastime fle youthfull pleasure

Let moderation allways be thy measure

And so prosed unto the heavenly treasure. III."

Second half of I7th century.

L. 2 ft. 3 in., W. $7 \frac{3}{4}$ in. Acquired in 1894.

19. Unbleached linen, decorated with cut and drawn work filled with needlepoint stitches. Eight horizontal bands of varying width, filled with wavy, leafy stems bearing conventional flowers and grapes, detached four-petalled blossoms, geometrical devices (including lozenges, rosettes and stars), and small S-shaped scrolls. A portion is left unworked at one end. Second half of 17 th century.

L. $22 \frac{1}{2}$ in., WV. $6 \frac{1}{2}$ in. Acquired in 1898.

20. Unbleached linen, embroidered with white linen thread, and further decorated with cut and drawn work filled with needlepoint stitches. Thirteen horizontal bands of varying width, filled with zig-zag stems bearing carnations, large and small lozenges enclosing rosettes, starlike flowers, and S-forms. Between them and below are four bands of openwork, one containing some of the letters of the alphabet (from A to U), and the others eight-pointed stars, S-forms, and crosses within octagons. Second half of $I$ th th century.

Plate V.

The lettering in this sampler is of remarkable beauty.

L. 3 ft. $2 \frac{1}{2}$ in., W. $6 \frac{1}{2}$ in Acquired in I898. Neg. Nos. 29r 49,37642 . 
21. Linen, decorated with cut and drawn work partly filled with needlepoint stitches. Twelve horizontal bands, the upper four filled with rosettes, acorns, birds, a hound chasing a hare, and leafy scrolls upon which parrots are perched; the remaining eight below contain geometrical devices. Second half of $I^{7}$ th century. PLATE IV.

L. $24 \frac{1}{2}$ in., W. $94_{4}^{3}$ in. Acquired in 1899.

Neg. No. $3763 \%$.

22. Unbleached linen, decorated with cut and drawn work filled with needlepoint stitches. Seven horizontal bands of varying width filled with various geometrical devices, including lozenges and octagons. Second half of I7th century.

L. $7 \frac{1}{2}$ in., W. $5 \frac{5}{8}$ in. Acquired in 1899 .

23. Unbleached linen, embroidered with coloured silks in cross and short stitches. Twenty-four horizontal bands varying in width, filled with leafy angular stems (some interlaced) and detached plants bearing pansiess, carnations, honeysuckle and other flowers, together with grapes, strawberries and acorns, and also S-forms. In one band are two standing male figures (boxers), each holding a flower (?). Second half of I 7 th century.

L. $2 \mathrm{ft}$. Io in., W. 7 in. Acquired in 1902.

\section{EIGHTEENTH CENTURY.}

(I) Dated.

24. Unbleached linen, embroidered with coloured silks partly in cross stitch. Horizontal bands varying in width; those at the top are filled with letters of the alphabet, the numerals and detached letters of various sizes, followed by the inscription :-

"Lord Give me Wisdom To Direct my Ways, I Beg not Riches nor Yet Length of Days. Martha. Wheeler Her Sampelr September The I5 I7Io ageed I2 Years The 2 Day of Last March."

Below is a broad band of zig-zag ornament, a narrower one of geometrical patterns, and others containing four detached floral sprays, a bottle, jug, and pot in blue and white earthenware, the latter containing a flower, a flying bird and various emblems. A portion at the bottom is left unfinished.

L. $18 \frac{3}{4}$ in., IV. 10 $\frac{1}{4} \mathrm{in.}$ Acquired in 1907.

Neg. No. 50109. 
25. Linen, embroidered with coloured silks partly in cross stitch. At the top are three bands varying in width, the first two filled with the letters of the alphabet three times repeated in large and small capitals, and the third with a zig-zag band in graduated colours and small detached sprigs of flowers. The lower part is worked with the Lord's Prayer, the name "ELISABETH CUTLER," and the date I7I7, within a large oval compartment surrounded by trailing leafy stems bearing roses, tulips, carnations, lilies, and other flowers.

L. $15_{4}^{1}$ in., W. 8 in. Presented by Harry Tipper, Esq., in r 912 .

26. Linen, embroidered with coloured silks, partly in cross stitch. Six horizontal bands of varying width filled as follows: (I) five hearts separated by pairs of birds and conventional plants or trees; (2) five trees, some bearing buds, with birds perched upon the branches, including two pelicans " in their piety," beneath is a hound pursuing a stag, a lion, and another animal; (3) flowers and plants between pairs of birds ; (4) in the middle a plant with curved stems issuing from a two-handled vase, and on either side a cavalier and his lady represented in Elizabethan costume ; there are small figures of "boxers" behind; (5) pairs of birds with flowering plants between; and (6) a narrow octagonal cartouche containing the following inscription: "Mary Smith Her Work made in the Year of our Lord I729," with two cupids supporting a crown above, and on each side stems bearing flowers and strawberries, also swans, animals and insects. The ladies wear red or blue dresses with train, open skirt and ruff, and the gentlemen a red or blue doublet, hose and cloak, with ruff. Probably copied from an earlier design.

L. II $\frac{3}{4}$ in. W. Io $\frac{1}{4}$ in. Presented by Miss Frances M. Beach in I9I6. Neg. No. 45580.

27. Unbleached linen, embroidered with coloured silks chiefly in small cross stitches. Horizontal bands of varying width filled with the Apostles' Creed, straight and zig-zag stems bearing honeysuckle, carnations and other flowers, the letters of the alphabet, the numerals, and the Lord's Prayer. At the bottom is the inscription: "Mary Chapman, her Work, ended in The I2 Year Of her age, I73r."

Plate V.

L. I7 in., W. 9 in. Presented by Miss Eyton in 1880.

Neg. No. 3764I. 
28. Woollen canvas, embroidered with coloured silks in close cross stitch. At the top are four rows of the alphabet in small and large letters, and an angular stem bearing conventional roses and other flowers. Below are the remaining letters of the alphabet, and some numerals, followed by the following inscription :-

"Gay dainty flowers, go swiftly to decay, poor wretched life's short portion flies away,

We eat, we drink, we sleep; but lo, anon, Old age steals on us, never thought upon.

Mary Wakeling Ended This, December The Tenth I742, Aged Ten Years."

There is a repeating border composed of an angular stem with honeysuckle and carnations.

I 2 in. square. Presented by Mrs. Leggatt in I878. Neg. No. 37628 .

29. Woollen canvas, embroidered with coloured silks partly in cross stitch. In the upper part, within an octagonal panel, is the Lord's Prayer, with the name " ELIZABETH CRIDLAND" and the date I752. Below is the following text from Proverbs xii. 24:

"The hand

of the diligent shall

bear rule but the slothfull

shall be under Tribute."

'The surrounding space is filled with a symmetrical arrangement in pairs of flowering trees, carnations growing from pots, pointed yew trees (?) with birds perched upon them, strawberries, cupids, birds, stags and dogs. At the bottom is a rural landscape showing houses, a dovecot, and a windmill.

One of the earliest known of the landscape class.

H. $13 \frac{1}{4}$ in., W. $9 \frac{3}{4}$ in. Presented by Miss Edmands in 1886 .

30. Loosely-woven canvas, embroidered in coloured silks, partly in cross and eyelet stitches. At the top are two horizontal rows of letters of the alphabet in capitals, and one row of numerals up to I2; below are the following two verses arranged in ten lines, and separated by a band of lozenge ornament :-

"Friends are like leaves that On trees do grow . in summers prosp'rous state much Love the show . but art thou in adversity than they . like laves from trees in autum full away. 
Bad Company As Deadly Poyson Shun thousands by It Are ruin'd And Undon the giddy Multytude Stil gose AStray turn From the broad And tuse the Narrow Way."

At the bottom is an octagonal compartment filled with the inscription :

$$
\text { " this }
$$

work in ha

nd my friends

mey have whe

n . I am dead and

laid in grave."

and the name " Ann Hunt."

The surrounding space is filled with a lion, stag, dog, butterfly, birds, crowns, oak-trees, stems of tulips, carnations and honeysuckle, symmetrically arranged. Beneath is a narrow border with a hunting scene, and the date 1770 . L. I $3 \frac{5}{8}$ in., W. $8 \frac{1}{2}$ in. Presented by Mrs. Wyman in 1917.

3r. Woollen canvas, embroidered with coloured silks in cross and satin stitches. In the middle is a square red brick house with five windows; there is a large pot of flowers on each side, together with birds, a lion, a stag and a squirrel. Above are conventional flowering plants, some growing from vases; also stars and birds. Below is an oblong compartment with the following inscription :-

$$
\text { " Catherine Pickling, }
$$
her work, aged 7 years, I780,"

with male and female figures bearing baskets of flowers or fruit on each side. There is a repeating border composed of a wavy stem with flowers and blossoms.

H. I $4 \frac{1}{4}$ in., W. $12 \frac{1}{4}$ in. Presented by Miss Edmands in 1886.

32. Woollen canvas, embroidered with coloured silks chiefly in chain stitch. A map of England and Wales, with the counties outlined in different colours, and a few towns also indicated. Several ships are represented upon the sea, and a rowing boat. In the lower left hand corner is the inscription: "Ann Rhodes, April the 26th I780. In the I3th year of her Age." The title "Map of England," and the date I780, is within a wreath also to the left, and there is a narrow border of latitude and longitude.

L. $24 \frac{1}{2}$ in., W. $21 \frac{1}{2}$ in. Presented by the Rev. J. Williamson in 1905 , 
33. Loosely-woven cotton, embroidered with red and blue silks in cross stitch. The upper half is filled with the letters of the alphabet, repeated twice, the numerals up to $I 4$, a crown and the date I789. The lower half has the name, "JANE HARRISON," surmounted by two small conventional trees and a vase of flowers. There is a narrow border consisting of an angular red stem and minute dark blue flowers.

L. $5 \frac{1}{2}$ in., W. $5 \frac{1}{1}$ in. Presented by Miss Grant in 1909.

34. Woollen canvas, embroidered with coloured silks in cross stitch. At the top is the following verse :-

"Dear mother I am young and cannot show such work as I unto your goodnefs owe

Be pleased to smile on this my small endeavour Ill strive to learn and be obedient ever."

In the middle, between wavy stems of carnation and honeysuckle, is a row of roses and tulips in pots or vases, a clipped tree with two stags beneath and birds flying above, also the following lines:-

" If all Mankind would live in mutual love

This world would much resemble that above."

At the bottom is the inscription: "Mary Ann Body Her Work in $y^{\text {e }} 9$ Year of her age I789," with a basket of flowers between two parrots; on either side is a windmill with dog beneath, and a square brick house with 7 windows. The border consists of a slight wary stem with yellow buds.

L. I4 in., W. I $2 \frac{1}{2}$ in. Presented by Miss Frances M. Beach, her maternal grand-daughter, in 1916.

35. Woollen canvas, embroidered with coloured silks, partly in cross and eyelet stitches. The map shows England and Wales, Scotland south of the Firth of Forth, the Eastern portion of Ireland, and part of the Northern coast of France. The counties are outlined in colours, with the name of each in black. The inscription: "Nap of England and Wales Work'd by Ann Gardiner March I7th I792," is within a floral wreath, tied with ribbons, in the top right hand corner. A " north point " and scale is worked on the left side. Beside the three capitals of London, Edinburgh and Dublin, only "Hwkshd" (Hawkshead, near Windermere,) is denoted amongst the towns.

H. $23 \frac{1}{2}$ in., IV. I9 $\frac{1}{2}$ in. In gilt frame glazed. Presented by Mrs. Antrobus in I9I6. 
36. Loosely-woven cotton, embroidered with coloured silks, partly in darning stitches. It bears the name " $M$. Sharman " and the date " July 26th I796." In the middle are stems of flowers (lilies, rosebuds, etc.), tied by a ribbon, with the name and date above and below. The surrounding space is filled with twelve crosses worked in various diaper patterns (lozenges, straight and zig-zag stripes). There is a border of a wavy stem with sprigs bearing berries attached. Similar work is on the English or Dutch sampler, dated I799. No. 37 .

I $4 \frac{3}{4}$ in. square. Bequeathed by the late Miss Pluckrose in I9I9.

37. Linen, darned with coloured silks and white linen thread. The pattern consists of twelve large crosses worked with various diapers (chiefly lozenges, chequers and stripes). In the middle is a square compartment containing the initials E.C. and the date I799. English or Dutch.

$\mathrm{I}_{3}$ in. square. Acquired in I899. Plate X

38. Canvas, embroidered with coloured silks, chiefly in cross and eyelet stitches. The upper half is worked with nine horizontal bands filled with the letters of the alphabet in capitals twice repeated and the numerals to ro. Below is lozenge ornament, with the inscription: "Phebe Nicholls Her Sampler Aged I3 Years February 9th I80o," the letters of the alphabet in smaller characters, and the following religious verse :-

"Why so offensive in some eyes

Doth God's Election seem

Because they think themselves so wise

That they have chosen Him."

L. 16 in., W. $7 \frac{1}{4}$ in. Presented by Mr. R. Linstead in I9I9.

(2) Undated.

39. Unbleached linen, embroidered with coloured silks in cross and satin stitch. The upper part is worked with seven bands of varying width, containing angular stems bearing carnations and strawberries, conventional trees and flowering plants (some growing from pots), fleurs-de-lis crowns, birds and windmills. In the middle portion is a small rose stem, and the greater part of the Lord's Prayer within an incomplete octagonal compartment. The lower part is plain. There is a narrow billet border all round. First half of I8th century. Apparently about the same date (I73I) as No. 27.

L. $18 \frac{1}{4}$ in., W. $8 \frac{3}{4}$ in. Presented by Miss Eyton in 1880 . 
40. Woollen canvas, embroidered with coloured silks, chiefly in cross stitch. (Unfinished.) A record of miscellaneous designs, consisting of small flowering plants, trees, blossoms, baskets of fruit, birds, a stag, a butterfly, crowns, and a wavy floral stem. In the middle is a square house with side columns and cupola, also with chequered marble pavement and grass plot in front. At the bottom is an irregular octagon decorated with stems of roses and other flowers, and filled with a soldier holding a rifle, and a man in crimson tail coat and yellow breeches beside a conventional tree. There is a small figure of a lady in the right lower corner. Latter part of I8th century.

L. $12 \frac{3}{4}$ in., W. $7 \frac{1}{2}$ in. Presented by Miss Frances M. Beach in 1916.

\section{NINETEENTH CENTURY.}

(I) Dated.

4I. Unbleached canvas, embroidered with coloured worsteds and silks in cross stitch. Ten narrow horizontal bands filled with the letters of the alphabet in capitals, and the numerals, separated by wavy and straight stripes. At the bottom is the name "MARIA SMITH" and the date I8Io. There is a repeating straight border of small blossoms.

L. $9 \frac{1}{4}$ in., W. $7 \frac{3}{4}$ in. Acquired in 1900.

42. Linen, embroidered with coloured silks chiefly in chain stitch. At the top are five horizontal bands of varying width containing the letters of the alphabet (repeated four times), the numerals (repeated twice), crowns and strawberries. In the middle is an octagonal panel enclosing the following verse :-

$$
\begin{aligned}
& \text { "May Plenty difsipate } \\
& \text { all worldly Cares } \\
& \text { And smiling Peace blefs } \\
& \text { my revolving Years." }
\end{aligned}
$$

above are the initials $\mathrm{L}$ Kq $\mathrm{P}$, and below is the name "MARY ANN CANN" and the date "Year I8oII" (probably meant for I8II or possibly I80I). The remaining space is filled with clumps of conventional trees, upon some of which birds are perched, angular floral stems, baskets containing flowering plants and fruit, stars, lions and dogs. There are also nine squares (not cut out) closely darned in colours, mainly in diagonal stripes. There is a border of fret pattern.

I $6 \frac{1}{2}$ in. by $15 \frac{1}{2}$ in. Acquired in 1899 . 
43. Unbleached canvas, with patterns in drawn work stitched round with coloured cottons. The letters of the alphabet in large capitals arranged in four horizontal rows. At the bottom are embroidered the words: "Maria Smith Her Work March 25th I8I3."

L. $7 \frac{3}{8}$ in., W. $8 \frac{1}{8}$ in. Acquired in 1900 .

44. Linen, with portions cut out and closely darned in white and blue cotton. Twenty-four squares (arranged in six rows of four) filled with various diaper patterns, such as dots, chequers, lozenges. At the bottom is worked in cross stitch the name "Susanna smith" and the date I8I6.

L. $17 \frac{1}{8}$ in., W. $10 \frac{1}{8}$ in. Acquired in 1900 .

45. Linen, with portions cut out and closely darned in white cotton. Fifteen squares (arranged in five rows of three) filled with various diaper-patterns, such as dots, chequers and lozenges. On the lower portion, the initials ss and the date 1816 are worked with blue cotton in cross stitch.

L. $12 \frac{1}{8}$ in., W. $7 \frac{3}{8}$ in. Acquired in 1900 .

46. Linen, with portions cut out and closely darned in white cotton. Fifteen squares (arranged in five rows of three) filled with various diaper patterns, such as dots, chequers and lozenges. On the lower portion the initials MS and the date 1816 are worked with red cotton in chain stitch. L. $12 \frac{1}{8}$ in., W. $7 \frac{3}{8}$ in. Acquired in 1900.

47. Woollen canvas, embroidered with coloured silks in cross stitch. In the middle is represented the Temptation of Adam and Eve in the Garden of Eden, with the surrounding space filled with birds, dogs, flowering plants (some growing from baskets), yew trees, crowns, hearts and other devices, symmetrically arranged in pairs. At the bottom is the following inscription :-." Amy Barnes her sampler aged I3 years," and the date I822. There is a border of a slender wavy stem with small blossoms.

L. $13 \frac{1}{8}$ in., W. $8 \frac{5}{8}$ in. Acquired in 1900 .

48. Woollen canvas, embroidered with coloured silks chiefly in cross stitch. In the middle is a conventional flowering tree with slender angular boughs, and the following verse above :-

"Patience will wipe away the streaming tear And hope will paint the palid cheek of fear Content will always happiness supply And vitrue call a blessing from on high.". 
The remaining space is filled with flowering plants (some growing from vases), detached blossoms and leaves, trees, birds, animals and butterflies symmetrically arranged in pairs. At the bottom is the name " HANNAH BLACKFORD," and the date I822. There is a border of a wavy floral stem.

L. 163 in., Wr. $13 \frac{3}{8}$ in. Acquired in 1899.

49. Woollen canvas, embroidered with coloured silks chiefly in cross stitch. In the midnle is a large symmetrical plant bearing roses and other flowers growing from a two-handled vase, surrounded by birds upon fruit-laden boughs, conventional plants (some growing from smaller vases), baskets of fruit, and dogs, all symmetrically arranged in pairs. At the top is the following verse :-

"If idly spent no art or care. Time's blessing can Restore.

And God requires a strict account For ev'ry mis-pent hour.

Short is our longest day of life. And soon its prospect ends.

Yet on that day's Uncertain date. Eternity depends,"

and at the bottom, within a small square compartment, is the name "HARRIOT TULLETT" and the date I826. There is a border of a wavy stem with carnations. PLATE VI. L. 16 in., W. $12 \frac{1}{2}$ in. Acquired in 1907.

Neg. No. 37633 ,

50. Woollen canvas, embroidered with coloured silks chiefly in cross stitch. At the top is the following verse :-

" Come gentle God without thy aid.

I sink in dark despair.

O wrap me in thy silent shade.

For peace is only there."

There are plants on each side and an angular floral stem above and below. In the middle within an oblong compartment is the inscription: "Sophia Starling wrought this sampler in the year I833," between two baskets of flowers with the rhyme "Love the Lord and he will be a tender Father unto thee." At the bottom is a row of plants and conventional trees. The border consists of flowering stems with rosebucls and other blossoms in the corners. The colours of the silks are mainly red, light blue, mauve (all faded), yellow, white and shades of green.

L. I $3 \frac{1}{2}$ in., W. I $3 \frac{1}{4}$ in. Presented by Mrs. Cushion in I92I. 
5I. Coarsely-woven yellow linen, embroidered with coloured cottons (chiefly blue, red, brown, and shades of green). At the top are five horizontal rows of the letters of the alphabet repeated four times, the numerals up to $I_{5}$, and four varieties of crowns. In the middle is the maxim "Honour thy Father and Mother in the days of thy Youth," an angular floral stem, and the inscription: "Ann Simmons April 6th 1835. Aged $\delta$ years." The remaining space is filled with conventional plants, some growing from pots, birds, a windmill, a heart, and detached blossoms. There is a straight stripe round the border (double on one side).

L. $15 \frac{1}{2}$ in., W. $16 \frac{3}{4}$ in. Presented by Mrs. Osmond in I9r 5 .

52. Woollen canvas, embroidered with coloured silks chiefly in cross stitch. At the bottom is a square house with five windows and a door, flanked on each side by a row of three trees, a hedge and rustic arch, there is a formal garden in front with lawns and paths, upon which are standing three ladies and a gentleman with small dog, also seats and vases of flowers. Above are large and small baskets and vases of flowers and fruit, cloud ornament, a vase, anchors, crowns and crosses, and at the top the following rhyme:-

"Let gratitude in acts of goodness flow Our love to God in love to man below

Be this our joy to calm the troubled breast Support the weak and succour the distrest Direct the wandrer dry the widows tear The orphan guard the sinking spirits cheer Though small our power to act though mean our skill God sees the heart he judges by the will,"

also the worker's name "Mary Pether" and the date I839. There is a continuous border of angular lily stems.

H. I $2 \frac{3}{4}$ in., W. $I_{5} \frac{1}{2}$ in. In black and gold wooden frame, glazed. Acquired at Oxford in 1920.

53. Linen, embroidered with coloured linen threads in cross and eyelet stitches. Eight horizontal bands of varying width filled with letters of the alphabet in capitals and smaller characters, and the numerals up to 30 . At the bottom is the inscription : " Lucy Heath April the 2I I842."

L. Io in., W. $16 \frac{1}{4}$ in. Presented by Mr. R. Linstead in I9I9.

(2) Undated.

54. Woollen canvas, embroidered with coloured silks in cross and satin stitches. At the top are four flying angels (two 
amidst clouds), beside a crown with the letters G. R. above. In the middle is an arch with two tall columns entwined with flowering stems, and surmounted by vases of plants, together with the words "The Temple of Fancy." Within an oblong compartment below is the following verse :-

\author{
" Not Land but Learning \\ Makes a Man complete \\ Not Birth but Breeding \\ Makes him truly Great \\ Not Wealth but Wisdom \\ Does adorn his State \\ Virtue not Honor \\ Makes him Fortunate \\ Learning Breeding Wisdom \\ Get these three \\ Then Wealth and Honor \\ Will attend on thee."
}

and the inscription: "Harriot Taylor, Ag'd. 7." At the bottom is a square house named "Queens Palace," standing in an enclosed garden of conventional trees, with squirrels and birds amidst the foliage. There is a wavy floral border. Worked in I8I3.

The date is given on the authority of a note on the original mounting.

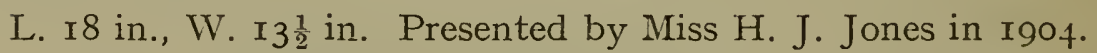

55. Unbleached canvas, embroidered with coloured cottons and silks in cross stitch. Seven horizontal bands of varying width, the first six filled with the letters of the alphabet in capitals (twice repeated), the numerals up to II, and the name "MATILDA SMITH"; the seventh band has a wavy floral stem. There is a small interlacing border. First quarter of Igth century.

Compare with No. 46, which has the initials M.s. worked upon it and the date I8I6.

L. $7 \frac{7}{8}$ in., WV. $7 \frac{5}{8}$ in. Acquired in 1900 .

56. Woollen canvas, embroidered with coloured silks in cross and satin stitch. At the bottom is represented a standing soldier or pensioner, wearing a red long-tailed coat, dark breeches, and cocked hat, a small square house surmounted by a pigeon-cot, conventional fruit-trees, a stag and other animals, and a bird. Above is a short horizontal band of parallel stripes in pale blue and white, also the inscription 
"This is my Dear Father." The remaining space is filled with winged figures blowing trumpets, peacocks and other birds, double-headed eagles, conventional flowering plants and baskets of fruit, some symmetrically arranged in pairs. There is a narrow border on three sides consisting of a wavy stem with small blossoms. First half of Igth century. L. $12 \frac{7}{8}$ in., W. $8 \frac{3}{4}$ in. Acquired in 1900 .

57. Canvas, embroidered with coloured silks and wools, and silver-gilt thread and gilt metal beads, and bordered with green velvet. The patterns consist of geometrical, floral, foliated and other designs, many of which are within rectangular compartments. At one end is a large piece of black velvet, lined with satin of the same colour, bordered with green velvet, and worked with floral designs in yellow silk. From the end of this piece hang two ribbons of olive-coloured satin. First half of Igth century.

L. Io ft. $\mathrm{I}_{4}^{\frac{1}{4}}$ in., W. 4 in. Presented by Miss Longhurst in rgro.

58. Loosely-woven linen, embroidered in coloured cottons with cross and eyelet stitches. Six horizontal rows with two alphabets (one in large capitals), and the numerals up to I3, divided by a wavy leafy stem, key, vandyke and pendant ornament. At the bottom is the inscription: "Charlotte Linstead Aged 8," with the figure of a dog. First half of Igth century. (About I830).

L. II in., W. $7 \frac{1}{4}$ in. Presented by Mrs. Linstead in I9I6.

59. Woollen canvas, embroidered with coloured silks in cross stitch. At the top are four narrow horizontal bands filled with the letters of the alphabet (partly in capitals) three times repeated, and the numerals to I7. In the middle are the following verses worked side by side :-

"How short is life's uncertain space

Alas how quickly done.

How swift the wild precarious chase

And yet how difficult the race.

How very hard to run.

Youth stops at first its wilful ears

To Wisdom's prudent voice.

Till advanc'd to riper years,

Experienc'd age worn out with cares

Repents its earlier choice."

At the bottom are the two lines:-

" Cast but a smile on this my first endeavour, I'll strive to mend and be obedient ever." 
First half of rgth century.

L. Io in., W. $12 \frac{3}{4}$ in. Presented by Mr. R. Linstead in 1919.

6o. Linen, embroidered with red linen thread with details in blue. The letters of the alphabet in capitals and smaller characters twice repeated, with the numerals to 9 , the initials " $\mathrm{Q} \mathrm{H} \mathrm{I} \mathrm{W"} \mathrm{and} \mathrm{a} \mathrm{floral} \mathrm{sprig,} \mathrm{arranged} \mathrm{in} \mathrm{five}$ horizontal rows. First half of Igth century.

L. $5 \frac{1}{4}$ in., W. $7 \frac{3}{4}$ in. Presented by Mr. R. Linstead in 1919. 


\section{DUTCH.}

DUTCH samplers are, generally, broad and square, with a somewhat detached pattern. Elaborate alphabets occur in several colours, as well as human figures, animals, birds, buildings and a variety of flowers. They are often dated and worked with initials. Small squares filled with darning stitches are not uncommon (No. 6r). Cross stitch is largely used and it is said that the embroidery is usually worked across the material, the selvage being left at the sides. ${ }^{1}$ No. 62 is of special interest since it bears the arms of the City of Amsterdam.

61. Cotton, embroidered with coloured silks, chiefly in darning stitches. Fifteen large cross-shaped panels and two small oblong ones filled with diaper patterns (stripes, chequers, lozenges, etc.) and floral and fruit sprigs. Towards the bottom is the date " ANNO I 763 " beneath a crown, with the name below "GERARDA GERRITSEN" and the letters "BY SS."

I $4 \frac{1}{2}$ in. square. Acquired in Holland. Presented by Mrs. Grove in I92I.

62. Linen, embroidered with coloured silks in cross stitch. Pattern of detached devices arranged symmetrically in pairs; they include fig and yew trees, roses, carnations and tulips, and other conventional plants (some growing from pots), flowers issuing from cornucopiæ, baskets of fruit, pairs of small figures (one a black man) holding eight-pointed standards, parrots, a peacock, cocks, and other birds, rabbits and dogs. At the top are the crowned arms of the City of Amsterdam with lion supporters; in the middle the initials A. C. B. (Amstelodunum Civitas Batavorum ?) and the date 1798 surmounted by a crown, within an octagonal wreath supported by two cupids, and at the bottom a recumbent stag between two flowering trees. There is a border of a wavy stem with blossoms. See also No. 37, a darned linen sampler of Dutch or English origin, dated 1798. Piate VII.

L. $2 \mathrm{I}$ in., W. $18 \frac{1}{2}$ in. Acquired in 1907. Neg. No. 37629.

(1) Mrs. C. J. Longman in Mr. Marcus Huish's Samplers and Tapestry Enbroideries, p. Iro. 


\section{FRENCH.}

THERE is at present scanty information available about samplers worked in France, but they are said to be usually dated and signed in full, and inscriptions are found upon some of them.' In No. 64-which appears likely to be of French origin-the varied emblems and floral designs are gracefully worked, and some of the sprigs and borders suggest records of the patterns used for the elaborate embroidered decoration of gentlemen's suits and ladies' dresses in the latter part of the I8th century. Two samplers recently acquired (Nos. 63 and 65) have designs of a religious character. One of them bears an inscription recording the fact that the work was done in a Convent School. It seems probable that this kind of sampler was usually produced in such surroundings.

(I) Dated.

63. Canvas, embroidered with coloured wools and silks. In the upper portion is represented an Altar at Exposition, with a monstrance on a small tabernacle, six candlesticks with lighted candles and four vases containing flowers standing upon it beneath the suggestion of a canopy. A strip of tiled floor is shown in front. The altar is surrounded by various Ornaments of the Sanctuary-two standard candlesticks (one on the right with one light, and another on the left with five lights), a chalice, an ewer and basin, a chair and small hand bell, holy water bucket and sprinkler, and a lamp, also the Sacred Trigram I.H.S. and the Emblems of a heart pierced with seven arrows, the crown of thorns, and an anchor with a wreath, and three nails. Above on each side of the Altar is the following inscription: "Faite par Miete Cheilan Agee de 8 Ans dans la classe des sœurs des Saints Noms de Jesus et de Marie Lancon I847." The lower portion of the sampler has a vase with conventional rose tree, two ducks and two trees, a lamb (the Agnus Dei ?) beside a small tower, and a credence table under an arch with cruet on a tray, cross and pyx placed upon it. The side borders are of vine stems with grapes, and the upper one represents a tasselled valance. The word "Lancon," occurring in the inscription, may refer to the town of Lançon in Provence, near Marseilles.

$2 I_{4}^{1}$ in. by 19 in. Acquired in $192 \mathrm{I}$.

(1) Mrs. C. J. Longman in Mr. Marcus Huish's Samplers and Tapestry Embroideries, p. III. 


\section{(2) Undated.}

64. White silk, embroidered with coloured silks, chiefly in satin stitch and French knots, silver-gilt thread and spangles. The upper part is filled with three rows of detached leafy sprigs, bearing roses, tulips, lilies, carnations, pansies, and other flowers, and strawberries. In the middle are portions of leafy borders, three wreaths, a sheaf of corn, a rake, a bow and arrow, and a cornucopia filled with flowers, all suspended by coloured ribbons; also a basket of flowers, an urn, and a butterfly. At the bottom are broken columns, a circular temple, a classical altar, a grotto, and trees. From Paris; last quarter of I8th century. L. II in., W. $16 \frac{1}{2}$ in. Acquired in Igor.

Neg. No. 39090.

65. Cotton, embroidered with coloured wools. At the bottom is represented an altar with cross, tabernacle, and six lights, and on each side two crosses. In the middle are the initials "G G" within a wreath, with the letters of the alphabet in two rows above. In the lower corners are two orange trees growing from tubs. The border consists of a wavy leafy and floral stem, with crosses at the corners. Early Igth century.

L. $9 \frac{1}{2}$ in., W. $12 \frac{3}{4}$ in. Presented by T. Frederic Wilson, Esq., in 1917 .

For a sampler from Alsace, see No. 74, on p. 33. 


\section{GERMAN.}

THESE are usually of linen, and they are worked with considerable length, the earlicst one in the Museum collection (No. 66), which is dated I68I, being about $3 \mathrm{ft} .6 \mathrm{in}$. (Plate VIII). The pattern-books of Hans Sibmacher, of Nuremberg, published in I59I and I604, with their geometrical designs, have been followed continuously until the Igth century. Copies of these books can be seen in the Museum Library. Between 1778 and $I 840$ both religious and allegorical subjects seem to have been popular, together with alphabets and numerals. ${ }^{1}$ Openwork horizontal bands filled with needlepoint lace stitches or drawn work were used to enrich the I 7 th century samplers, as in England, and sacred emblems, small landscapes, and heraldry were also introduced (see Nos. 67, 68, and 7I). The initials of the worker, together with the date, were placed within a garland or small frame, but inscriptions are rarely found. Darned squares, with the material completely cut away beneath, occur on German samplers earlier in the ISth century than on English ones. There is another class of sampler dating from the first half of the Igth century, which was produced in the Vierlande, a district on the Flbe near Hamburg (Plate IX). Specimens are square in shape, and they are closely worked in black cotton with geometric devices, birds, and conventional flowers in pots, also various domestic artićles, often represented minutely (Nos. 69 and 70). Cross stitch is mainly used on the earlier samplers, but the quality is sometimes coarser than on contemporary English samplers; at a later date a greater variety of stitches was used.

\section{(I) Dated.}

66. Linen, embroidered with coloured cottons chiefly in cross stitch. At the top are many close narrow borders of straight and wavy ornament, and scallops copied from contemporary lace edgings. Below are ten horizontal bands filled with fruit-bearing trees, carnations, and other flowers (some growing from vases), floral devices, angular stems with roses and pomegranates,.stags and other animals, birds, and lozenge ornament. There are

(1) See J. Brinckmann, Das Hamúurgische Museum, pp. 59, 60. 
also the letters of the alphabet, and the numerals, worked upside down in six rows. At one side are the initials "GEF" and the date I68I.

Plate VIII.

L. 3 ft. $6 \frac{1}{2}$ in., W. $9 \frac{1}{2}$ in. Acquired in 1872 . Neg. No. 37632 .

67. Loosely-woven unbleached canvas, closely embroidered with brightly coloured silks partly in cross and satin stitches. Twenty-one horizontal bands and square or oblong compartments, filled with geometrical diapers (including lozenges, zig-zag stripes, overlapping squares, and scale ornament), and also with detached or wavy stems bearing carnations, tulips, lilies, and other flowers. In the lower right-hand corner, upon a green ground, is the Sacred Trigram, I.H.S., within a floral wreath, with two coats-of-arms ${ }^{1}$ below having helmets, mantling, and crests, and at the bottom edge the initials " $\mathrm{D} \mathrm{M} \mathrm{W}$ " and the date 1688 .

L. 23 in., WV. 9 in. Acquired with the Robinson collection in I88o.

Neg. No. 37634

68. Woollen canvas, embroidered with coloured silks in chain stitch. In the middle is a vase on a pedestal with parrot above within a wreath, surrounded by various objects, and including a tower amidst rocks and trees, a onemasted ship, a couchant lion, a galloping horse, also pairs of small birds, cocks, a stag, dog, cat, and other animals, flowers in pots, and a basket of fruit. At the top are the letters of the alphabet in capitals twice repeated, a crown, the initials "T. K." and the date I709 (apparently meant for I790). There is a striped blue linen selvage on each side. The style of this sampler makes the date i709 impossible. IO $\frac{5}{3}$. in. square. Acquired with the Forrer collection in 1899 .

69. Linen, embroidered with black cotton in cross stitch. Five irregular rows of circular and lozenge-shaped devices containing geometrical patterns, also double-headed eagles, conventional plants and pairs of stags; above is a row of four vases from which grow roses, lilies and other flowers. The remaining space is closely filled with a peacock, owls and smaller birds, dogs; stags, smaller geometrical and plant forms (such as stars, hearts and rosettes), also various domestic articles-a chair, a key,

(1) Gules a man (seen to three quarters) vested sable with conical cap, holding to the dexter with both hands a branch (?) ; crest; a demi-man as in the arms, full face. Or a woman (seen to three quarters) vested sable with tall hat holding with right hand a flower gules; crest; a woman as in the arms. 
and a gridiron. At the top are the letters of the alphabet repeated twice, the numerals, the initials "T.K.W.B." (also worked at the bottom edge) and the date "ANNO I807." From the Vierlande, a district on the Elbe near Hamburg.

Plate IX.

L. 20 in., IV. I $6 \frac{1}{2}$ in. Acquired in 1899.

Neg. No. 37637 .

70. Linen, embroidered with black cotton in cross stitch. The greater portion is filled with rows of rosettes and octagons of geometrical patterns, large and small flowering plants growing from vases (some with conventional stags beneath), owls and other birds, pairs of cupids with the word "ANNo," and narrow fragments of borders of wavy stem or link pattern. At the top are the letters of the alphabet in rows repeated ten times in various types (the last row being beneath crowns), the numerals, the name "MARIA GÖTTLICH," and the date I848. From the Vierlande, a district on the Elbe near Hamburg.

L. I 5 in., IT. I $6 \frac{1}{2}$ in. Acquired in 1899.

\section{(2) Undated.}

71. Iinen, decorated with cut and drawn work and needlepoint lace fillings, and also embroidery in black or white cotton. The upper portion consists of fifteen horizontal bands of varying width in openwork with patterns of rosettes and stars (some within lozenges), and trefoils; below are three bands worked in white with angular floral stems and the letters of the alphabet, also a heart transfixed by arrows worked in black. At the botton is a pointed compartment of geometric pattern in openwork. From Nuremberg; I7th century.

It is interesting to compare this with an English sampler of the same period, see No. 4. The work in the German sampler is not so varied and is coarser in quality.

L. 2 ft. $8 \frac{1}{2}$ in., W. $8 \frac{3}{4}$ in. Presented in 187 I by Mrs. Henry Reeve.

72. Loosely-woven muslin, decorated with drawn work and embroidery in white cotton thread. Thirty-five small squares (arranged in seven rows of five each) filled with various diapers, including lozenges, quatrefoils, horizontal, diagonal and zig-zag stripes and chequer pattern. There is a scalloped border of wavy leafy stems and floral devices partly outlined in chain and buttonhole stitches. It is bound with pale blue ribbon, with bows at the corners (one missing). Probably from North Germany: first half of Igth century. Compare with Swedish sampler, No. I38. 
This panel resembles peasant work from Flemish settlements on the Elbe, see a Cap Front, No. IIgo-r883, and some of the "Tönder" drawn work, see Introduction, p. 5.

L. $10 \frac{1}{2}$ in., W. $11 \frac{1}{2}$ in. Pink paper backing. Acquired in 1903 .

73. Squared net, decorated with needle-run embroidery, darning (lacis), and applied cambric outlined with embroidery. Thirty-six square compartments in six rows of six each, filled with lozenges, blossoms, horizontal and vertical stripes, interlacements and other diaper patterns. There are three borders, varying in width, consisting of floral devices (with elaborate fillings), hearts, crosses and other geometrical forms. The compartment and borders are outlined by stripes of pink floss silk, and the outer edge is bound with silk ribbon and corner bows of the same colour. Probably from North Germany; first half of Igth century.

See No. 72, and also a panel with similar diapers from East Prussia, No. 7 80-I905.

L. I $8 \frac{1}{2}$ in., W. $17 \frac{1}{2}$ in. Green paper backing of double thickness. Acquired in 1903 .

\section{FROM ALSACE.}

74. Loosely woven linen, embroidered with coloured silks chiefly in chain stitch. At the top are the letters of the alphabet repeated twice. In the middle are the initials " M. O. B." and the date I7I 8 , surrounded by symmetrically curved stems bearing flowers and fruit; beneath is a twohandled vase of lilies, and pots with a lemon and apple(?) tree stand in each of the lower corners. At the sides are four small square panels closely worked with various diapers, including zig-zag lines, lozenges and flowers. The remaining space is filled with detached stems of tulips and other flowers, a basket of fruit, also a peacock, parrot and other birds.

L. $12 \frac{1}{2}$ in., W. $9 \frac{3}{4}$ in. Acquired in 1907. 


\section{ITALIAN.}

TALIAN samplers often illustrate lace-making, but there 1 is only one of early date in the Nuseum. This specimen is the large sampler recently acquired from the collection of the late Mr. Henry Wallis (No. 77) ; it belongs to the I 7 th century (Plate XII). An interesting record of similar Italian patterns, both for embroidery and lace, of late I6th and carly I7th century date, is illustrated in Signora Elisa Ricci's recent book: Antiche Trine Italiane. ${ }^{1}$ It shows a square linen panel, now in the possession of the Marchesa Eloisa Bargagli of Florence, divided into four equal parts, three of which are worked in coloured silks with graceful floral borders somewhat resembling those reproduced upon contemporary English samplers, and the fourth with geometric devices in reticella and cut and drawn work. Another sampler of about the same period $^{2}$ is mainly composed of small horizontal bands of reticella, with some in white work, of floral and geometrical design. Some Igth century embroidered samplers which are still found in Italy, sometimes bearing the name of the town upon them, are believed to have been worked by American or English residents in that country ${ }^{3}$; others record Italian names, such as "Teresa Fini" or "Maria Pagani." 4 Four specimens from Perugia (Nos. 75, 76, 79 and 80) have been lately acquired by gift.

\section{(I) Dated.}

75. Loosely-woven linen, embroidered with coloured silks in cross stitch. At the top commencing with a floriated cross is the alphabet in adapted Lombardic capitals, arranged in two horizontal rows, which terminate with the date 1820 . In the middle is a vase of fruit, with a peacock on one side and stag on the other, a carnation and other flowering plants. At the bottom are unfinished designs (a scalloped band, the peclestal of a vase, and part of a stag).

L. $7 \frac{1}{4}$ in., W. $13 \frac{1}{t}$ in. Acquired at Perugia. Presented by Miss Leonora F. M. Preston in I9I6.

(1) Trine ad Ago. Vol. I. Punto a lieticello Tav. I ${ }^{a}$.

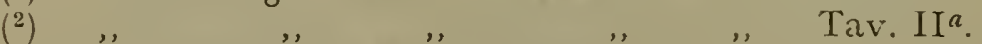

(3) Note supplied by MIrs. Hungerford Pollen.

(4) On samplers in the collection of Dr. J. W. Walker, of Chicago. 
76. Linen, embroidered with coloured silks in cross stitch. At the top commencing with a cross terminating in crowns are two alphabets in cursive and Roman capitals of varying size, and the numerals up to Io, and by tens up to roo, arranged in four horizontal rows. In the middle is a band with the inscription: "vitTORIA $x$ LUCHETTI $\mathrm{x}$ FECE $\mathrm{x}$ LANNO $\times 1855 \mathrm{x}$," and at the bottom an unfinished row consisting of a basket of fruit, with - pairs of birds perched on vases of flowers, cypress trees, and dogs on each side, and also four small panels of lozenge diaper. The vertical side borders are filled with two-handled vases from which grow flowering plants; at the top is a horizontal band of interlacing key ornament.

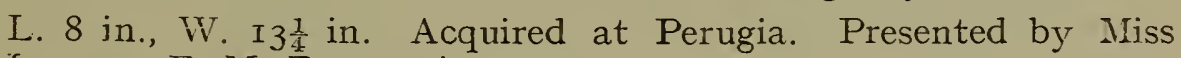
Leonora F. MI. Preston in IgI6.

\section{(2) Undated.}

77. Linen, with needlepoint lace, cut and drawn work, and embroidery in silver and white linen thread. The upper half consists of horizontal lace bands of varying width, filled with large and small rosettes, stars and other geometrical devices, and flowering stems. In the left corner, beneath the name "GVLLIA PICCOLOMINI," 1 is the figure of a lady in a wide striped skirt holding a flower. The lower half has broad and narrow bands of white embroidery and openwork, with lozenges, geometrical ornament, the Sacred Trigram I.H.S. within rays, and various floral devices. I 7 th century.

Plate XII.

L. $2 \mathrm{ft} .7 \frac{1}{4}$ in., W. I 7 in. Acquired in I9I9. Formerly the property of the late Mr. Henry Wallis.

Neg. No. 50 I08.

78. Linen, embroidered with coloured silks chiefly in cross stitch. The pattern is arranged in two horizontal compartments; the upper one filled with small buildings, crowned monograms, conventional trees, floral devices and a wavy stem bearing acorns, the lower with a woman dressed in a pale red bodice, blue skirt and black hat, a doorway and an iron gate, two windows (open and closed), birds perched on a railing, and another upon a tree with a fox beneath (perhaps representing Fsop's fable of the Fox and the

(1) The name Giulia was borne in several branches of the Piccolomini family of Siena: e.g., Giulia (b. I 549), who married Alessandro d'Elci in 1579; Giulia (b. 1655), daughter of Count Francesca Piccolomini, wife of Sigismondo Trapp, baron of Biseno, and Giulia (b. 1647), wife of Girolamo Cerretani, in I668. Cf. A. Lisini and A. Liberati: Genealogia dei Piccolomini di Siena, Tav. III, V, VI, I900. 
Crow). There is a narrow border of a wavy stem with blossoms. Said to have been acquired in Florence. Late I 8 th or early I9th century.

Plate X.

$9 \frac{3}{4}$ in. by $9 \frac{1}{8} \mathrm{in}$. Presented by Miss Baxter in I912, on behalf of her late sister, Miss Kate Baxter.

Neg. No. 37638 .

79. Linen, embroidered with coloured silks in cross and eyelet stitches. At the top are two alphabets in capitals of varying size arranged in two horizontal rows, and at the sides are two further alphabets and the numerals up to 9 within rectangular compartments. In the middle is a bouquet of flowers, surrounded by stems bearing flowers and fruit, floral sprigs, birds, butterflies, a vase and basket of flowers or fruit, a ewer, and ruins and other buildings; beneath is the name "viRgINIA ROCCHI." In the lower corners are represented a woman with a rake in a field, and a man fishing out of a boat. There is a narrow border all round of repeating stems of roses and other flowers, partly of wavy character. First half of Igth century.

L. I $3 \frac{3}{4}$ in., W. 20 in. Acquired at Perugia. Presented by Miss Leonora F. M. Preston in 19I6.

80. Cotton, embroidered with red cotton, chiefly in cross stitch. At the top are three alphabets in Roman and cursive capitals of varying size each commencing with a cross (the first terminating with the initials $A G$ ), and the Arabic and Roman numerals up to 9, arranged in four horizontal rows. Below are the following Sacred Emblems: a Heart with the Sacred Trigram I H S above, a lily growing from a pot, a chalice and paten (?) ; also a crown, a cat, birds, a cypress tree, and other objects, besides wavy floral and leafy stems. The border consists of key and cable ornament, and detached straight or wavy stems bearing flowers, fruit and leaves. About middle of Igth century.

L. $8 \frac{1}{2}$ in., W. 20 in. Acquired at Perugia. Presented by Miss Leonora F. M. Preston in I9I6. 


\section{SPANISH.}

THESE are distinguished by their vivacious colouring and variety of design. They are usually of large size, sometimes about 24 in. square, or of oblong shape. They are entirely covered with numerous border patterns, chiefly of graceful floral character. In the square samplers these are worked round the four sides, and the centre is filled with Sacred Emblems, doubleheaded eagles (part of the insignia of the Hapsburg kings of Spain), or monograms. In the oblong samplers the borders are arranged in two vertical rows with a join resembling a seam down the middle. The edges are often decorated with small tassels of floss silks or bows of coloured silk ribbon. Satin and cross stitches are used, as well as drawn work bound over with coloured silks. Alphabets rarely occur, but the name of the worker is usually recorded in full, together with the date, and on six specimens in the Museum collection the teacher's name is added (Nos. 83, 84, 92, I05, II6 and I25). The earliest dated sampler of Spanish origin in the Museum (Plate XI.) bears the year I756 (No. 8I). The collection has been greatly strengthened by the gifts of Dr. W. L. Hildburgh, F.S.A., who obtained many samplers in embroidery and drawn work during his recent travels in Spain. Samplers made in Mexico are generally smaller, and show similar design to the traditional patterns upon those from Spain, although dated examples are generally of the rgth century (Nos. 89 and 90). ${ }^{1}$

\section{(I) Dated.}

81. Linen, embroidered with coloured silks in a great variety of stitches (including satin and chain stitch), and further decorated with drawn work. The greater part is divided into seven rectangular compartments, six of which are filled with horizontal bands of varying width, containing lozenges, floral devices, wavy and scrolling stems, and other ornament. The middle compartment has two winged kneeling figures, between which is a monogram formed of the letters B V R (?), a pyramidal building with columns and hanging lamps, a conventional female figure holding leafy branches on each sicle, pairs of birds, and detached flowers. Round three sides runs the following inscription: "DOÑA ISABEL

(1) See English Illustrated Magazine, XXXII, 1904-5, illustration on p. 446 . 
EVlogia DE LA ESPADA LOACAVo. ANo DE I756." (Doña Isabel Eulogia de la Espada finished it in the year I756.) There are also two narrow panels of drawn work at the sides, with patterns in green and pale red silk, of a doubleheaded eagle between two lions (?), and geometrical devices. Wide borders surround the whole sampler, consisting of oblique and zig-zag bands, lozenge-shaped and other geometrical figures, and floral designs. It is edged with pink silk ribbon.

Plate XI.

L. 2 ft. $5 \frac{1}{2}$ in., IV. 2 ft. $4 \frac{3}{4}$ in. Acquired in 1909. Neg. Nos. 37630 , 37631 .

82. Linen, embroidered with brightly coloured silks (green, blue, and shades of yellow and red), in a great variety of stitches (including satin, chain, and cross stitch), and further decorated with drawn work In the centre is a double-headed eagle with a Maltese cross on its breast and a crown above, also the name "THERESA CASARES" and the date " AÑO DE I762" below, surrounded by bands of rosettes, stars and other geometrical devices. Between this central compartment and the outer border are further bands of drawn work in zig-zag and diagonal stripes, lozenges and lattice-work patterns. The outer border is broad, and is filled with rows, varying in width, of conventional plantforms, angular fioral stems and ornamental bars. In each corner is a square compartment enclosing an angular plant surrounded by small birds and detached blossoms. There are small tassels of blue and yellow silks at the corners (one missing), and a straight drawn-work edging.

L. 2 ft. 7 in., IV. 2 ft. $3 \frac{1}{2}$ in. Presented by Lary Stern in IgII. Reproduced in Review of the Principal Aquisitions, I9II, P. $5 I$, fig. 33 .

Neg. No. 35238.

83. Linen, embroidered with coloured silks chiefly in cross stitch. In the middle is a large rectangular compartment filled with a variety of objects, including a carnation plant growing out of a two-handled vase, flowering plants in smaller vases, a fountain with birds and animals on either side, chairs, ships, etc. ; around is the inscription: "ME IZO TIBVRCIA DE I.ARAONA DISCIPVLA DE NICOLA SA MONTES ANO DE MIL [SI] ETECIENTOS NOVENTA I NVEVE." (Tiburcia de Laraona, pupil of Nicola sa Montes, made me in the year one thousand seven hundred and ninety nine.) The borders consist of a narrow one with key ornament between two broad ones with geometrical patterns of lozenges containing stars or crosses, treble stripes and a row of vases (?).

L. $23 \frac{1}{2}$ in., W. $21 \frac{1}{2}$ in. Acquired at Burgos. Presented by Dr. IV. L. Hildburgh, F.S.A., in I9I 7 . 
84. Linen, embroidered with coloured silks in a great variety of stitches (including cross and satin stitch). The patterns are very numerous, and consist of a lady carrying a flower, accompanied by four dogs, a man and a lizard, a shepherd with his sheep, a double-headed eagle and smaller birds, flowering plants growing from 'vases, the sun and moon, the Sacred Trigram I.H.S. and various religious emblems, and many bands of geometrical diapers, blossoms and angular floral stems. The middle panel is surrounded by the following inscription, worked in black: "MEIZO DOÑA RAMONA X ERIZARDE X SIENDO SU MAESTRA DOÑA LUISA DE TOROCA II EDELHORNO DE SAÑ MATIAS AÑO DE I8I2(?). (Doña Ramona Erizarde made me, her teacher being Doña Luisa de Toroca $y($ ?) Edelhorn de San Matias, in the year I8I2.) The edges are bound over with blue and buff coloured silk, and at each corner is a bow of coloured silk ribbon (blue, pink, green and yellow).

$2 \mathrm{ft} .4$ in. by $2 \mathrm{ft} .3$ in. Acquired in 1884 .

85. Linen, embroidered with coloured silks in chain stitch. In the centre is the date 1832 , surrounded by a miscellaneous arrangement of landscapes with trees and houses, birds perched on branches or flying, sprigs of roses, tulips and other flowers, wavy floral stems, and baskets of fruit or - flowers. The inner border is filled with two repetitions (and portion of a third) of the letters of the alphabet in capitals, and the numerals up to Io. The narrower outer border consists of a row of small squares.

I $4 \frac{1}{2}$ in. by $14 \frac{1}{4}$ in. Acquired at Toledo. Presented by Dr. W. L. Hildburgh, F.S.A., in I917.

86. Linen, embroidered with coloured silks, partly in cross stitch. Divided in the length by a central vertical line. The left half contains a monstrance beneath a red valance with tasselled cords, the inscription in capitals: "LOHIZO JOSE FA ALONSO ANO DE I832" (Josefa Alonso made it in the year I832), a pot of carnations, floral borders and keyr ornament. The right half has the arms of Castile and Leon between the pillars of Hercules, a chair, two ships, and seven horizontal bands of geometrical and floral pattern (lozenges, hexagons, crosses and zig-zag stripes).

L. $9 \frac{3}{4}$ in., W. 8 in. Acquired at Toledo. Presented by Dr. W. I, Hildburgh, F.S.A., in 1919.

87. Linen, embroidered with coloured silks in cross stitch. In the middle is the inscription: "LOHIZO DIONISIA GUZMAN EN SORIA ANO DE IS44 (Dionisia Guzman made it in the 
year I 844$)$; above are trees, flowering plants in vases, a house, a small key, and the letters of the alphabet in capitals; below are two stags beside a fountain, small birds, pots of flowering plants, and a row of slender twohandled vases containing flowers. There is a variety of borders all round, consisting of floral sprigs, straight and wavy floral stems, lozenge diaper, and a row of pots with flowers, leaves and fruit.

L. I 2 in., W. $14^{\frac{3}{4}}$ in. Acquired at Burgos. Presented by Dr. W. L. Hildburgh, F.S.A., in 1917.

88. Linen, embroidered with coloured silks chiefly in cross stitch. Round the middle is the following inscription : "ABECEDARIO . ECHO . DE LAMANO . DE FLORENTYNA . LOPEZ . ENCALERA . ANO . DE . I848." (Alphabet made by the hand of Florentyna Lopez at Calera in the year I848.) Within is a carnation plant growing from a basket, surrounded by a transfixed heart, small birds and dogs, a ship, a ladder, a high-backed chair, and pots of flowers. There are borders all round of floral and geometrical patterns (interlaced hexagons, lozenges, and dentated ornament), with scrollwork arcading and stripes.

I $4 \frac{1}{2}$ in. by $I_{4} \frac{1}{4}$ in. Acquired at Burgos. Presented by Dr. W. L. Hildburgh, F.S.A., in I9I7.

89. Linen, embroidered with brightly coloured silks (partly in cross and satin stitch) and copper-gilt thread, and further decorated with drawn work. Twelve bands filled with lozenges, zig-zag stripes, angular floral stems, doubleheaded eagles and masks. There is also a stag holding a flower in its mouth (within a squarish compartment), two symmetrical stems bearing flowers and fruit, a rose and a carnation plant growing from vases, the Sacred Trigram I.H.S., a pelican and smaller birds, monkeys and other animals. At one side is the following inscription, worked in black: "LO HISO M ${ }^{A}$ DE JESÛS BALERIA LARA, SE ACABO EL DIA 8 DE ENERO. DE I65I." (Maria de Jesûs Baleria Lara made it, finished the 8 day of January I65I.) Probably meant for $\mathrm{I}_{5} \mathrm{I}$. From Mexico.

L. $2 \mathrm{ft} .7$ in., W. $15 \frac{1}{4}$ in. Acquired in 1899 . The date is probably a mistake, as another Spanish sampler, dated I850, shows workmanship and design almost precisely similar. See photograph at Catalogue Stall, No. 25574; and the following Sampler, No. 90.

90. Linen, embroidered with brightly coloured silks (partly in cross and satin stitch) and copper-gilt thread, and further decorated with drawn work. Fifteen horizontal bands 
arranged in groups of three, filled with lozenges, diagonal and zig-zag stripes, angular and wavy floral stems and S-shaped scrolls, all on an open ground. There are also ten bands with geometrical patterns, and angular and scrolling stems bearing conventional flowers and pomegranates in embroidery, and in the upper right-hand corner is worked a symmetrical floral stem, with a small house and vase at the edge. In one drawn-work compartment the following letters and numerals are left in the linen :-

"E. D. LO. I

F. L. E. E. A. 52."

Probably meant for 1852 . From Mexico.

23 in. by $22 \frac{1}{4}$ in. Acquired in 1899 . See preceding sampler, No. 89.

91. Linen, embroidered with coloured silks and wools in cross stitch. Various detached designs, including two black and white dogs, an ox, a basket of fruit, a scrollwork device, the letters of the alphabet in large capitals, the initials " $O \mathrm{P}$ " and the date 1854 .

L. 23 in., W. ro $\frac{1}{2}$ in. Acquired at Burgos. Presented by Dr. W. L. Hildburgh, F.S.A., in 1917 .

\section{(2) Undated.}

92. Linen, embroidered with coloured linen threads (green, blue, pink and buff) and green silk in cross stitch. Twelve horizontal bands of varying width, filled with eight-pointed stars, lozenges, crosses, zig-zag stripes, and conventional flowers. The border has a closely repeating row of finial devices in alternating groups of blue, yellow, green and pink. Towards the lower end is the following incomplete inscription in green silk :-

$\begin{array}{llr}\text { "LOHIZO MARIA DE } & \text { LAO } \\ \text { GVZMAN i BERGARA. } & \text { Dis } \\ \text { CiPVLA DE } & \text { FRANCISCA DE } & \text {..." }\end{array}$

(Maria De Lao Guzman y Bergara made it, pupil of Francesca de ...) I 7 th or I8th century.

L. 2 ft. 2 in., W. 44 in. Acquired in 189 r. Neg. No. 39083.

93. Linen, embroidered with coloured linen threads (green, blue, pink and buff) in cross and satin stitch. Twenty-one horizontal bands of varying width filled with lozenges, rosettes, angular stems, cupids holding scrolls, stags, horses, birds, vases of flowers and floral devices. Along the two sides is an inner border consisting of a row of scallops, and all round is an outer border of repeating S-shaped floriated 
scrolls in blue. There are small tassels of coloured linen threads at the corners and at the middle of each side. i 7 th or I 8 th century.

L. 3 ft. 4 in., W. 22 in. Acquired in $189 \mathrm{r}$.

Neg. No. 39084 .

94. Linen, embroidered with white linen thread and blue cotton. The surface is divided into twelve horizontal bands of varying width, filled with angular leafy stems, floral sprigs, detached blossoms and different geometrical patterns (lozenges, stars, crosses and zig-zag stripes). There is a narrow repeating border of striped ornament all round. r 7 th or 18 th century.

L. 2 ft. 3 in., greatest WV. I3 in. Acquired at Toledo. Presented by Dr. W. L. Hildburgh, F.S.A., in I9I7.

95. Linen, embroidered with coloured silks in satin and other stitches. In the middle are two winged figures supporting a monogram formed of the letters $\mathrm{V} P \mathrm{R}($ ?), a pyramidal building with columns and hanging lamps, a conventional female figure richly dressed and holding a leafy branch on each side, pairs of birds, animals and floral devices. Above is the inscription: "LO HIZO ANA MARIA LEAL." (Anna Maria Leal made it.) The remaining space is filled with many horizontal bands and vertical borders, varying in width, consisting of scrolling floral stems and geometrical devices (including hexagons, lozenges, diagonal stripes and rosettes). In each corner is a square compartment filled with an angular plant. There is a repeating border of rosettes, detached flowers and zig-zag stems, and a narrow edging of fringed pink silk. Middle of $\mathrm{I} 8 \mathrm{th}$ century.

The middle compartment resembles No. 79, and the corners are like those of No. 61 .

L. $2 \mathrm{ft} .10_{4}^{\frac{1}{4}}$ in., W. 2 ft. 2 in. Acquired in 1897 . Neg. No. 44718.

96. Linen, embroidered with coloured silks, chiefly in coarse cross stitch. Long and narrow in shape. Ten horizontal bands varying in width, filled with lozenge, zig-zag, chequer, octagon and other geometrical patterns, and linked leafy stems. There are twelve small tassels round the edges of coloured silks, in yellow, brown and blue. ISth century.

L. 2 ft. I $\frac{1}{2}$ in., IV. $8 \frac{3}{8}$ in., including tassels. Acquired in I9I 2 .

97. Linen, embroidered with coloured silks (chiefly yellow, green, blue and shades of red) in a variety of stitches, including satin, chain and darning stitches. In the middle is an oblong compartment containing a floral device enclosing the arms of the Carmelite Order ${ }^{\mathbf{1}}$; it is

(1) Cf. Woodward's Ecclesiastical Heraldry-Carmelites. 
surrounded by the following inscription: DOÑA . MICAELA . Vsebia . I . V . A . N . O VR . (Doña Micaela Usebia Juano . . .), with narrow floral borders all round. The surrounding space is worked with a wide repeating border consisting of symmetrical plants, some growing from baskets, alternating with pairs of oxen and birds. Long and short borders arranged both vertically and horizontally, with squares at the corners, fill the rest of the sampler; they are worked with various floral and geometrical patterns, some of lozenge and chevron character. I8th century.

L. $2 \mathrm{ft}$. $I$ in., W. $16 \frac{1}{2}$ in. Acquired in 1893.

98. Linen, with cut and drawn work bound over with cotton thread. There is also slight embroidery in coloured cotton. Divided in the width by a central vertical line. The left half is divided into seven horizontal bands and the right into four bands of varying width, all with geometrical patterns (lozenges, zig-zag stripes, S-forms, angular or leaf devices, etc.). The embroidery is on the lower part of the right side, and chiefly consists of a lozenge diaper in blue and red. Probably I8th century.

L. $7 \frac{1}{4}$ in., W. $2 \mathrm{I} \frac{1}{2}$ in. Acquired at Toledo. Presented by Dr. W. L. Hildburgh, F.S.A., in I9I7.

99. Linen, enbroidered with red and blue cottons. Divided in the width by vertical lines into five divisions, which are worked with thirty horizontal bands, of varying width, containing a number of geometrical diapers (lozenges and crosses), $\mathrm{S}$ and $\mathrm{X}$-shaped devices, floral and dentated lace.like edging, also small plants, finial devices and birds. I8th century (?).

L. $9 \frac{1}{2}$ in., W. 24 in. Acquired at Toledo. Presented by Dr. W. L. Hildburgh, F.S.A., in I9I 7.

I00. Linen, embroidered partly in cross stitch with coloured silks, blue cotton and white linen. In the middle is a tall, slender, two-handled vase surmounted by a large crown, and surrounded by pairs of lions, birds, small plants and the two Sacred Monograms; floral devices are in the corners. Around this compartment is the inscription: "LEHISO DIONISIA GOMEZ DE A . GVERO DE EDAD DE IIANOS." (Dionisia Gomez de Aguero made it at the age of eleven years.) There are two broad borders all round consisting of a double row of plant forms and large lozenges containing four or eight petalled-flowers. I8th century.

L. $2 \mathrm{ft} .6$ in., W. $23 \frac{1}{2}$ in. Acquired at Toledo. Presented by Dr. W. L. Hildburgh, F.S.A., in I 917 . 
Ior. Linen, with cut and drawn work bound over with white and light brown cotton thread. The name " RAIMvNDA MARTINIA" is worked with red cotton in cross stitch. Divided in the width by a central vertical line. The left half is divided into eight horizontal bands and the right half into seven bands of varying width, with geometrical patterns (lozenges, zig-zag stripes, and S-forms), leaf devices and a wavy stem. Probably I8th century.

L. IO $\frac{1}{2}$ in., W. I 7 in. Acquired at Toledo. Presented by Dr. W. L. Hildburgh, F.S.A., in I9I7.

102. Linen, with cut and drawn work, bound over with brown and white linen thread. There is also slight embroidery in red cotton and brown linen thread. Divided in the width by a central vertical line. The left half is divided into twelve horizontal bands, and the right half into ten bands, of varying width, containing different geometrical patterns (lozenges, S-forms, $\mathbf{X}$-shaped and rectangular devices). Probably I8th century.

L. $13 \frac{1}{4}$ in., greatest W. 2 ft. $5 \frac{1}{4}$ in. Acquired at Toledo. Presented by Dr. W. L. Hildburgh, F.S.A., in 1917 .

I03. Iinen, with cut and drawn work bound over with white cotton thread and green, red and blue silks. Divided in the width by a central vertical line. The left half is divided into five horizontal bands and the right half into twelve bands of varying width, containing different geometrical and floral patterns (lozenges, zig-zag bands, S-forms, $\mathrm{X}$-devices, pointed leaves and eight-petalled flowers). Probably I8th century.

L. I $4 \frac{1}{2}$ in., greatest W. 20 in. Acquired at Toledo. Presented by Dr. W. L. Hildburgh, F.S.A., in I9I7.

I04. Linen, embroidered with coloured linen and cotton threads (red, blue and shades of brown). Divided in the length and width by vertical and horizontal lines. The right hand top quarter has five horizontal bands, of varying width, filled with geometrical ornament (lozenges, angular devices, $\mathbf{X}$-shaped crosses and quatrefoils) ; the remaining quarters are worked with a variety of geometrical diapers (lozenges enclosing crosses, zig-zag stripes and S-forms) and also with dentated lace-like edgings, plant forms, and pairs of birds. I8th century (?).

L. I $8 x$ in., W. I9 in. Acquired at Toledo. Presented by Dr. W. L. Hildburgh, F.S.A., in 1917. 
I05. Linen, embroidered with coloured silks, chiefly in cross stitch. In the middle is a fountain with double bowls upon which birds are perched, surrounded by small baskets of fruit, a vase of flowers and an animal, within a dentated edging. The border has the letters of the alphabet in capitals, and the inscription: "LOICO PETRA FERNANDEZ ENLAEFSE NANCA DEGEFERINA . ARIAS." (Petra Fernandez made it under the teaching (enseñanza) of Geferina Arias.) I8th century.

$6 \frac{1}{2}$ in. by $6 \frac{1}{4}$ in. Acquired at Toledo. Presented by Dr. W. L. Hildburgh, F.S.A., in I9I 7 .

I06. Linen, embroidered with coloured silks and blue linen thread in cross stitch. In the middle is a large double cross with pyramidal base, surrounded by smaller crosses, birds and lions, and three bands of lozenge pattern. There are four borders all round filled with lions, and geometrical ornament (lozenges, dentations, etc.). I8th century.

$2 \mathrm{I} \frac{1}{4}$ in. by $2 \mathrm{I}$ in. Acquired at Toledo. Presented by Dr. W. L. Hildburgh, F.S.A., in I9I9.

107. I.inen, with cut and drawn work bound over with brown and white cotton, and embroidery in red cotton. Divided in the width by a central vertical line. The left half is worked in the upper part with dentated lace-like edgings and floral borders, below are four horizontal bands with geometrical ornarnent in openwork (lozenges, circles, quatrefoils, etc.). The right half has four horizontal bands of varying width, with angular carnation stems, pairs of dogs, sprigs, leaf and hexagonal ornament. Probably I8th century.

L. $22 \frac{1}{4}$ in., W. IO $\frac{1}{4}$ in. Acquired at Burgos. Presented by Dr. W. L. Hildburgh, F.S.A., in I9I 7 .

I08. Linen, with cut and drawn work partly bound over with red and buff-coloured cotton. Divided in the width by a central vertical line. The two halves are filled with seventeen horizontal and parallel bands of varying width. They contain detached leaves and blossoms, wavy floral stems, four-petalled flowers within large lozenges, and geometrical patterns-chiefly variations of a lozenge diaper. Probably I8th century.

L. $20 \frac{1}{2}$ in., W. 24 in. Acquired at Burgos. Presented by Dr. W. L. Hildburgh, F.S.A., in I9I7.

I09. Linen, embroidered with brown linen thread and red and blue cotton. The left half is covered with five horizontal bands of varying width filled with star-like flowers, large 
lozenge and $\mathrm{X}$-shaped devices; the right has many portions of narrower bands with various geometrical diapers (lozenges, crosses, zig-zag stripes, etc.), and at the bottom detached plant devices. I8th century.

L. I 5 in., WW. $16 \frac{3}{4}$ in. Acquired at Burgos. Presented by Dr. W. L. Hildburgh, F.S.A., in 1917 .

I Io. I.inen, with cut and drawn work, bound with white cotton and partly with red and blue silk. Divided in the length and width by vertical and horizontal lines. The lower quarters and the left upper one have each four bands, and the right upper one nine bands, of varying width, filled with angular devices, S-forms, and lozenge diapers (sometimes enclosing crosses or stars) and other geometrical patterns. Probably I8th century.

L. I6 in., W. I 7 in. Acquired at Burgos. Presented by Dr. W. L. Hildburgh in I9I7.

I I I. Linen, with cut and drawn work, bound over with white cotton, and partly with pale red and blue silk. Divided in the width by vertical lines into three parts, which are covered with twenty-four horizontal bands, of varying width, containing eight-petalled flowers within large lozenge-shaped compartments, and different geometrical patterns (lozenges, some enclosing crosses and stars, zig-zag stripes, etc.). Probably I8th century.

L. I $4 \frac{1}{4}$ in., W. $22 \frac{1}{2}$ in. Acquired at Burgos. Presented by Dr. IV. L. Hildburgh, F.S.A., in 1917 .

I 2. Linen, with embroidery in red and blue cotton and cut and drawn work partly bound over with buff-coloured cotton. It bears the inscription " DOROTE FRERO P." (Dorothy Erero.) Divided by two lines into quarters. The upper quarters and part of one of the lower are closely worked with a variety of geometrical diapers (lozenges, S-forms and key pattern) and floral designs of detached plant forms and wavy stems. The remaining portions of the lower quarters have eleven horizontal bands in openwork of similar geometrical character. Probably I8th century

L. I $3 \frac{1}{2}$ in., W. about $\mathrm{I}_{4} \frac{3}{1}$ in. Acquired at Burgos. Presented by Dr. W. L. Hildburgh in I9I7.

I I3. Linen, with cut and drawn work bound over with cotton thread. Divided vertically in the width into three parts, which are filled with twenty-five horizontal bands, of varying width, containing geometrical patterns (lozenges, 
rosettes, zig-zag stripes and S-forms. On one side is the inscription: "LOIZO LORENZA MOR" (I.orenza Mor made it) embroidered in red. Probably I8th century.

L. $x_{4}$ in., W. 8 in. Acquired at Burgos. Presented by Dr. W. L. Hildburgh, F.S.A., in I9I 7.

II4. Linen, embroidered with cotton in red and shades of brown. It is closely covered with plant forms, rectangular and lozenge-shaped floral devices, rows of sprigs, pairs of birds and narrow ornamental stripes. I8th century (?).

L. $9 \frac{1}{2}$ in., IV. $1 \circ \frac{1}{2}$ in. Acquired at Burgos. Presented by Dr. W. L. Hildburgh, F.S.A., in I9I 7 .

II5. Linen, embroidered with coloured silks, chiefly in cross stitch. In the middle there are four horizontal bands of varying width, filled with lozenges, zig-zag stripes and conventional carnation stems, also a small female figure and a chair; there are broad and narrow borders of geometrical ornament. I8th century.

L. I5 in., greatest IV. I6 $\frac{1}{2}$ in. Acquired at Burgos. Presented by Dr. W. L. Hildburgh, F.S.A., in 1917 .

I I6. Linen, embroidered with coloured silks, partly in cross stitch. In the middle is a squarish compartment filled with a large carnation plant with angular stems growing from a vase, and surrounded by detached blossoms, stars and keys; around the compartment is the inscription: "LOHIZO MARIA DEL PILAR SAEZ DISCIPULA DE DOÑA ROSA GARCIA . VIVA . JESV." (Maria del Pilar Saez made it, pupil of Doña Rosa Garcia. Hail Jesu!). The outer borders are of varying width, and consist of geometrical ornament (lozenges and crosses), with dentated and chequer patterns. I8th century.

$\mathrm{r}_{5}$ in. by $\mathrm{I}_{5} \frac{1}{4}$ in. Acquired at Burgos. Presented by Dr. W. L. Hildburgh, F.S.A., in 19 I 7 .

I 7 . Linen, embroidered with coloured silks in cross stitch. In the middle is a squarish compartment with the letters of the alphabet in capitals at the top, and below flowering plants in vases, the Agnus Dei, birds, gridirons, a basket of fruit, a ship, and other objects. The outer borders vary in width, and consist of geometrical ornament (hexagons, crosses, zig-zag stripes) with scroll and chequer patterns. I8th century.

L. I $2 \frac{1}{4}$ in., W. 13 in. Acquired at Burgos. Presented by Dr. W. L. Hildburgh, F.S.A., in I9I 7. 
I 8 . Linen, embroidered with coloured silks and red, white and blue cotton. There are also slight traces of drawn work. Closely covered with various borders, both broad and narrow, and detached sprigs, arranged horizontally. The borders consist of wavy and zig-zag floral stems, S-forms, lozenges, and star-shaped blossoms. The drawn work is in a lozenge pattern. Probably I8th century.

L. I 7 in., W. $9 \frac{1}{2}$ in. Acquired at Burgos. Presented by Dr. W. L. Hildburgh, F.S.A., in 1917.

I I9. Iinen, with cut and drawn work and embroidery in coloured silks. Divided vertically in the width into three parts, which are filled with twenty-eight horizontal bands of varying width (four of them in openwork), containing geometrical patterns (lozenges, hexagons, diagonal, zig-zag and straight stripes), blossoms and floral devices, pairs of birds and a row of slender columns. Probably I8th century.

L. I $5 \frac{1}{2}$ in., W. 2 ft. $2 \frac{1}{4}$ in. Acquired at Seville. Presented by Dr. W. L. Hildburgh, F.S.A., in I92I.

I20. Linen, embroidered with coloured silks partly in cross stitch. The upper part is worked with a two-masted ship, two pots with flowering plants, a basket of fruit, a small cross on a mound, and various letters of the alphabet. Below are the consecutive letters of the alphabet in capitals, repeated twice. The borders consist of lozenges enclosing crosses, a zig-zag stripe and a straight floral stem. Late I8th century.

L. $15 \frac{1}{4}$ in., W. 17 in. Acquired at Burgos. Presented by Dr. W. L. Hildburgh, F.S.A., in I9I7.

I2I. Linen, embroidered with red and blue cotton thread. Divided in the width by a central vertical line into six horizontal bands in each half, of varying width, closely filled with lozenges, S-forms, $\mathrm{X}$-shaped devices, interlacing and leaf ornament. I8th or early I9th century.

L. $8 \frac{3}{4}$ in., W. $2 \mathrm{I}$ in. Acquired at Toledo. Presented by Dr. W. L. Hildburgh, F.S.A., in 1917.

I22. Linen, embroidered with coloured silks in cross stitch. In the middle compartment is the inscription: "LOHIzO VICENTA MORENO PARA DONA PETRA SALAMANCA ENLAMAESTRAD . M.S." (Vicenta Moreno made it for Dona Petra Salamanca during the mistress-ship . xx.) Above is a band of rosettes within hexagons, and below a row of lanterns and conventional plants. There are three borders 
of varying width, the outer one of key pattern in blue, and the inner two of diagonal ornament and carnation plants. Second half of I8th or early Igth century.

L. I3 in., W. I7 in. Acquired at Toledo. Presented by Dr. W. L. Hildburgh, F.S.A., in I919.

I23. Linen, embroidered with coloured wools chiefly in cross stitch. In the middle is a square-shaped compartment filled with a large star device, the letters " $G$. . . NYAPE . • ," a two-headed eagle, the Agnus Dei, and floral patterns. The remaining surface has geometrical ornament (lozenges and crosses) and plant forms, with a border of lions all round. I8th or early Igth century.

L. 2 ft. $4 \frac{1}{2}$ in., W. I9 in. Acquired at Toledo. Presented by Dr. W. L. Hildburgh, F.S.A., in I9I9.

124. Linen, embroidered with brown linen thread, and blue and red cotton. Divided in the width by a central vertical line. The left half is worked towards the top with a variety of geometrical diapers (lozenges, crosses and key pattern), and below with dentated lace-like edgings, detached plants and flowers, an animal, birds and a heart device; the right half is filled with nine horizontal bands of varying width containing $\mathrm{S}$ and $\mathrm{X}$-forms, lozenges, rosettes and key pattern. I8th or Igth century.

L. I $4 \frac{1}{2}$ in., W. $22 \frac{1}{2}$ in. Acquired at Burgos. Presented by Dr. W. L. Hildburgh, F.S.A., in I9I 7 .

I25. Linen, embroidered with coloured silks chiefly in cross stitch. In the middle is a dronping tree, a ship, a basket of fruit, birds and floral sprigs. Around are several borders of varying width containing rows of vases, stems of carnations and other flowers, and lozenge diaper enclosing crosses. The innermost border is filled with the inscription : "LOHIZO JOSE FADIEZ . DISIPUIA DE DA MANVELA LOPEZ MTRA DE LA ENCN." (Jose. Fadiez made it pupil of Dona Manuela Lopez-of the Incarnation.) Late I8th or early Igth century.

About I $3 \frac{1}{4}$ in. square. Acquired at Burgos. Presented by Dr. W. L. Hildburgh, F.S.A., in I9I 7 .

126. Linen, embroidered with red cotton in cross stitch and coloured silks Seven repetitions in horizontal rows of the letters of the alphabet, chiefly in capitals. In the top lefthand corner is a floral medallion suspended from a bow of ribbons above a scalloped edge, on the right is a crowned double-headed eagle, and at the bottom is a small basket of fruit. First half of Igth century.

L. $7 \frac{1}{8}$ in., W. 2 I in. Acquired at Toledo. Presented by Dr. W. L. Hildburgh, F.S.A., in I917. 
I27. Linen, embroidered with coloured silks in cross stitch. A medley of straight and wavy floral stems, a rose tree growing out of a vase, two baskets of fruit, and birds. First half of Igth century.

L. 7 in, W. Io in. Acquired at Toledo. Presented by Dr. W. L. Hildburgh, F.S.A., in I9I7.

r28. Linen, embroidered with coloured silks in cross stitch. A. medley of patterns, including large and small figures of men (one on horseback), a goat, a stag, a pair of doves and other birds, ships, carnation and other plants growing from vases, a basket of fruit, sprigs of flowers, a small key, and narrow bands of lozenge or chequer diapers. First half of Igth century.

L. $8 \frac{1}{4}$ in., W. $9 \frac{1}{4}$ in. Acquired at Toledo. Presented by Dr. W. L. Hildburgh, F.S.A., in I9I7.

I29. Linen, embroidered with coloured silks chiefly in cross stitch. In the middle is an oblong compartment, with the initials " J.M.A.M." surrounded by small lozenges in red, green and light blue. There are borders of geometrical ornament (lozenges, dentations, and stripes) partly in mauve and yellow. First half of Igth century.

L. $7 \frac{1}{2}$ in., W. I I $\frac{1}{8}$ in. Acquired at Toledo. Presented by Dr. W. L. Hildburgh, F.S.A., in I9I9.

I30. Linen, embroidered with coloured silks in cross stitch. In the middle is a basket with a carnation plant and two rosebuds, and two small birds perched on the handles, a small dog, and floral sprigs, and the initials " T.H." and "B.P." The remaining space is filled with finial devices and geometrical ornament (hexagons, lozenges, and diagonal stripes). It is bound with linen braid, with linen bows at the corners. First half of Igth century.

L. II $\frac{1}{2}$ in., W. $6 \frac{1}{2}$ in. Acquired at Toledo. Presented by Dr. W. L. Hildburgh, F.S.A., in IgI9.

I3I. Canvas, embroidered with coloured silks in cross stitch. In the middle are standing figures of a peasant woman carrying a basket, and a man with a stick ; the inscription " POR TERESA FERNDZ" (By Teresa Fernandez), is worked below. There are two borders all round, the inner one filled with star devices, and the outer with rose-stems. First half of Igth century.

L. $22 \frac{1}{4}$ in., W. about 24 in. Acquired at Burgos. Presented by Dr. W. L. Hildburgh, F.S.A., in I9r7. 
132. Linen, embroidered with coloured silks and red and blue cotton in cross and eyelet stitches. At the top are eleven narrow stripes of straight or zig-zag character, together with various letters of the alphabet in capitals. At the bottom are four baskets of fruit and several birds. The remaining surface is unworked. First half of Igth century. L. II $\frac{1}{2}$ in., W. I6 $\frac{3}{4}$ in. Acquired at Burgos. Presented by Dr. W. L. Hildburgh, F.S.A., in $19 \mathrm{I} 7$.

I33. Linen, embroidered with coloured silks in cross stitch. In the middle is a carnation plant in a large basket, together with birds, vases of flowers, baskets of fruit, and wavy floral stems. Above are the letters of the alphabet in capitals, the numerals up to 9 , and the inscription " LA 3 DE MAYO LA CRUZ." (The Third of May [Feast of the Finding of] the Cross.) The borders consist of angular vine-stems with grapes, wavy stems bearing roses, and other flowers, and a row of vases of flowers and baskets of fruit with rabbits between. First half of Igth century.

L. II in., W. I8 in. Acquired at Burgos. Presented by Dr. IV. L. Hildburgh, F.S.A., in I 917 .

134. Linen, embroidered with coloured silks, chiefly in cross stitch. At the bottom a man in red and blue costume is riding a grey horse towards a house on the left; behind him is a pyramidal object or cypress tree (?). At the top left-hand corner is part of a row of large eight-petalled rosettes in pink and light blue, with floral ornament between. First half of Igth century.

L. I 8 in., W. 20 in. Acquired at Burgos. Presented by Dr. W. L. Hildburgh, F.S.A., in I9I7.

I35. Linen, embroidered with coloured silks partly in cross and chain stitch. At the bottom is a two-handled vase from which grows a flowering plant, with a basket of fruit on each side; above is a tabernacle (?), and two pots of flowers. The remaining space is filled with a pair of small dogs, butterflies, vases, and ewers. There is a narrow border of zig-zag and diagonal lines. First half of Igth century.

L. $7^{\frac{3}{4}}$ in., W. I I in. Acquired at Burgos. Presented by Dr. W. L. Hildburgh, F.S.A., in I9I 7 .

136. Linen, embroidered with coloured silks partly in cross stitch. In the middle is a stag standing upon grass, the background is worked in white with a small lozenge diaper (unfinished). There are three borders, a broad one filled 
with floral sprigs, lozenges and hexagons, between two narrow ones of squares and dentated ornament. First half of Igth century.

L. ro in., W. I I 3 in. Acquired at Burgos. Presented by Dr. W. L. Hildburgh, F.S.A., in 1917.

I37. Canvas, embroidered with coloured wools in cross stitch. In the middle are represented the emblems of the Passion, the Sacred Trigram I.H.S., roses and other flowers, leafy stems, human figures, trees, ships, and the initials "E.R." There are a number of borders of varying width, composed of geometrical ornament (lozenges, crosses, zig-zag and wavy stripes). Middle of Igth century.

L. ${ }_{4} \frac{1}{2}$ in., W. $21 \frac{1}{2}$ in. Acquired at Toledo. Presented by Dr. W. L. Hildburgh, F.S.A., in 1919. 


\section{SCANDINAVIAN.}

SAMPLERS from Sweden and Denmark are not very $S$ numerous, but some are found with patterns in white embroidery and cut and drawn work corresponding to the decoration on articles of costume produced in the I8th and Igth centuries (No. I38). An important specimen has been acquired lately (No. I39); the donor obtained it in Copenhagen about fifteen years ago.

\section{SWEDISH.}

138. Linen, with cut and drawn work and embroidery in coloured cottons. The middle has five horizontal bands, of varying width, filled with geometrical ornament (crosses, stars, lozenges, etc.). The central band is worked in red with the letters $\mathrm{S} \mathrm{K} \mathrm{A}$ and the date I863, flanked by two birds. There are three borders, the inner and outer ones of drawn work, and the middle one in green and brown, all of geometric patterns. In each corner is a sprig bearing tulip-like flowers and leaves, with a small red cross at the edge. Worked by peasants at Ska in the province of Uppland, Sweden. Compare with North German (?) sampler, 'No. 72.

L. $15^{\frac{3}{4}}$ in., W. $15^{\frac{1}{4}}$ in. Presented by Mrs. Bury Palliser in 1869 .

\section{DANISH.}

I39. Canvas, embroidered with coloured silks, partly in petit point. At the top is a horizontal band of geometrical ornament (stars and crosses within lozenges), with a landscape showing a river, a church, a windmill and other buildings, flanked by the letters of the alphabet in capitals and smaller type, and the numerals up to $2 \mathrm{I}$. The middle is filled with a wreath of roses, carnations and other flowers containing initials, with a flying angel on each side blowing a trumpet, surrounded by smaller wreaths, a vase of flowers, a basket of fruit, a melon, birds, a ship, the initials A.H.H. and M.K.E. beneath crowns, the Sacred Trigram I.H.S., and the date I798. At the bottom is represented the Crucifixion and the Temptation in the Garden of Eden, with a basket of pears between. Probably Danish.

Sight measure, $14 \frac{1}{4}$ by $13 \frac{1}{8}$ in. In black and gold frame, glazed. Acquired in Copenhagen. Presented by Mrs. Grove in I92r. 


\section{LIST OF USEFUL WORKS ON SAMPLERS IN}

THE LIBRARY OF THE MUSEUM.

All of these, except Mr. Lediard's article, have numerous illustrations. Mr. Huish's book contains many coloured reproductions and is an exhaustive study of the subject.

Bolton, Ethel Stanwood and Coe, Eva Johnston. American Samplers. I92I.

Brinckmann, J. Das Hamburgische Museum für Kunst und Gewerbe. Die Stickmustertücher. Pp. 59-63. I894.

Christie, Mrs. Archibald H. Embroidery and Tapestry Weaving, ch. vii, p. I48. I906.

Fothergill, G. A. Notes on Scottish Samplers. (In: Proceedings of the Society of Antiquaries of Scotland, Vol. XLIII, pp. I80-205. I908-9.)

Head, Rachel E. A Collection of English Samplers. (In : The Connoisseur, Vol. II, pp. I64-I70. I902.)

The Sampler: Its Development and Decay. (In: The Reliquary, Vol. VIII, pp. II-20. I902.)

The Stitchery of Samplers, with a note on their materials. (In: Samplers and Tapestry Embroideries, by Marcus B. Huish, pp. I6I-I7I. I9I3.)

The Lace and Embroidery Collector, ch. xix, pp. 2I2-232. I922.

Huish, Marcus B. Samplers and Tapestry Embroideries. Second edition, IgI3.

The Samplers of our lovely Ancestresses. (In: Art in America, Vol. III, pp. I24-I33. April, I9I5.)

Jourdain, M. Some English Samplers. (In: The ArtWorkers' Quarterly, Vol. IV, pp. 59-62. I905.)

Samplers. (In: The. History of English Secular Embroidery, ch. xi. I9IO.)

Kendrick, A. F. English Embroidery, pp. 96-98, ro3-5. I904.

LEDIARD, H. A. On Samplers. (In: The Archceological Journal, Vol. LVII, pp. 24I-247. Igoo.) 
Lewer, Florence. The Sampler. (In: The Essex Review, Vol. XVII, pp. I46-I57. I908.)

Nutrall, G. Clarke and Sloane, M. S. Samplers. (In: The English Illustrated Magazine, Vol. XXXII, pp. 438-446. I904-5.)

Palliser, Mrs. Bury. History of Lace. Footnotes to p. 9, also p. 23. 4th edition. 1902 .

Peacock, Florence. Samplers. (In: The Reliquary, Vol. IV, pp. I74-I82, I898, and The Architectural Review, Vol. VII, pp. 7I-8I, I900.)

Ricci, Elisa. Antiche Trine Italiane. Trine ad Ago. Vol. I. Punto a Reticello, Tav. $\mathrm{I}^{\mathrm{a}}$ and $\mathrm{II}^{\mathrm{a}}$ I908.

TUER, ANDREW W. History of the Horn Book. Vol. II. ch. xii, pp. 239-259. 1896.

White, Gleeson. The Sampler : an Appreciation and a Plea for its Revival. (In : The Studio, Winter Number, I896-7, pp. 58--7r.)

For references to Sampler Poesy, see Notes and Queries. Vols. VI and VII, 4th Series. 


\section{NUMERICAL INDEX I.}

\begin{tabular}{|c|c|c|c|c|c|c|c|}
\hline $\begin{array}{l}\text { Registered } \\
\text { No. }\end{array}$ & $\begin{array}{l}\text { Catalos } \\
\text { No. }\end{array}$ & & Page. & $\begin{array}{l}\text { Registered } \\
\text { No. }\end{array}$ & $\begin{array}{l}\text { Catalog } \\
\text { No. }\end{array}$ & gue & Page \\
\hline $234-1869$ & . 138 & . & 53 & I379-I900 & . 43 & . & $2 I$ \\
\hline I326-I87I & $7 I$ & . & 32 & I380-I900 & $4 \mathrm{I}$ & . & 20 \\
\hline $323-1872$ & 4 & $\cdots$ & 9 & I38I-I900 & 55 & . & 24 \\
\hline $512-I 872$ & 66 & . & 30 & 83-IgOI & 64 & . & 29 \\
\hline 5I6-I877 & I7 & . & I2 & $75 \mathrm{I}-\mathrm{IgO} 2$ & I & . & 8 \\
\hline 804-I877 & 5 & . & 9 & 829-I902 & 23 & . & I4 \\
\hline $394-I 878$ & 28 & . & I6 & II 8 I-I903 & 72 & . & 32 \\
\hline IO4-I 880 & 67 & . & $3 I$ & II 82-I903 & 73 & . & 33 \\
\hline $469-I 880$ & 27 & . & I5 & 9I8-I904 & 54 & . & 23 \\
\hline $470-I 880$ & 39 & . & I9 & 497-I905 & 32 & . & I7 \\
\hline $433-I 884$ & I I & . & IO & IOI7-I9O5 & 3 & . & 8 \\
\hline $609-I 884$ & 84 & . & 39 & I45-I907 & 24 & . & I4 \\
\hline $288-I 886$ & 29 & . & I6 & 368-I907 & 6 & . & 9 \\
\hline $289-1886$ & $3 I$ & . & I7 & 369-I907 & 49 & . & 22 \\
\hline $240-I 89 I$ & 92 & . & $4 I$ & $842-I 907$ & 62 & . & 27 \\
\hline $24 I-I 89 I$ & 93 & . & $4 \mathrm{I}$ & 9I6-I907 & 74 & . & 33 \\
\hline $435-1893$ & 97 & . & 42 & 44-I908 & 2 & . & 8 \\
\hline $480-I 894$ & I 8 & . & I3 & T.II-I909 & 33 & . & I 8 \\
\hline $476-\mathrm{I} 897$ & 95 & . & 42 & T.I29-I909 & $8 I$ & . & 37 \\
\hline $47-I 898$ & I9 & . & I3 & T.333-I9IO & 57 & . & 25 \\
\hline $269-I 898$ & 20 & . & I3 & T.209-IgII & 82 & . & 38 \\
\hline II3-I899 & Io & . & IO & T.2I4-IgII & 9 & . & IO \\
\hline 5I0-I899 & 69 & . & $3 I$ & T.79-IgI2 & 25 & . & I5 \\
\hline 5II-I899 & 70 & . & 32 & I.I2I-I9I2 & 96 & . & 42 \\
\hline 59I-I899 & . & . & 9 & T.I95-I9I2 & 78 & . & 35 \\
\hline $74 I-I 899$ & 8 & . & IO & T.20-I9I3 & I3 & . & II \\
\hline $742-I 899$ & $2 I$ & . & I4 & T.82-I9I3 & I 5 & . & I2 \\
\hline $744-1899$ & 22 & . & I4 & T.83-I9I3 & I. 6 & . & I2 \\
\hline $79 I-I 899$ & 90 & . & 40 & T.76-I9I5 & $5 \mathrm{I}$ & . & 23 \\
\hline $792-I 899$ & 89 & . & 40 & T.IOI-I9I5 & I2 & . & II \\
\hline I379-I899 & 68 & . & $3 I$ & T.7-I9I6 & $5^{8}$ & . & 25 \\
\hline I979-I899 & 37 & . & I9 & T.23-I9I6 & 79 & . & 36 \\
\hline I98I-I899 & 42 & . & 20 & T.24-I9I6 & 76 & - & 35 \\
\hline I982-I899 & 48 & . & $2 I$ & T.25-I9I6 & 75 & . & 34 \\
\hline I372-I900 & 47 & . & $2 \mathrm{I}$ & T.26-I9I6 & 80 & . & 36 \\
\hline I373-I900 & 56 & . & 24 & T.273-I9I6 & 35 & . & I 8 \\
\hline I376-I900 & 44 & . & $2 I$ & T.290-I9I6 & 40 & . & 20 \\
\hline I377-I900 & 45 & $\cdots$ & $2 I$ & T.29I-I9I6 & 26 & . & I5 \\
\hline I378-I900 & 46 & . & $2 I$ & T.292-I9I6 & 34 & $\cdots$ & I8 \\
\hline
\end{tabular}




\section{NUMERICAL INDEX I-cont.}

\begin{tabular}{|c|c|c|c|c|c|c|c|}
\hline $\begin{array}{l}\text { Registered } \\
\text { No. }\end{array}$ & $\begin{array}{c}\text { Catalogu } \\
\text { No. }\end{array}$ & & Page. & $\begin{array}{c}\text { Registered } \\
\text { No. }\end{array}$ & $\begin{array}{c}\text { Catalog } \\
\text { No. }\end{array}$ & & Page \\
\hline T.42-I9I7 & . 65. & . & 29 & T.I73-I9I7 & . 126 & & 49 \\
\hline T.43-r9r7 & 30 & . & Í́ & T.I74-I9I7 & 102 & & 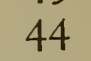 \\
\hline T.I44-I9I7 & . 107 & . & 45 & T.I75-I9I7 & I03 & . & \\
\hline T.I45-I9I7 & . 108 & . & 45 & T.I76-I9I7 & I $2 I$ & $\cdots$ & fo \\
\hline г.I46-I9I7 & . I I I & . & 50 & T.I77-I9I7 & 127 & . & 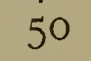 \\
\hline T.I47-I9I7 & .. 87 & . & 39 & T.I78-I9I7 & I04 & . & \\
\hline T.I48-I9I7 & . . I32 & . & $5 I$ & T.I79-IgI7 & 105 & . & \\
\hline T.I49-I9I7 & .. I33 & $\cdot$ & $5 I$ & T.I80-IgI7 & .. 128 & $\cdots$ & \\
\hline T.I5O-I9I7 & .. 88 & . & 40 & T.I8I-I9I7 & .. 85 & . & \\
\hline T.I5I-I9I7 & . . I34 & $\cdots$ & $5 \mathrm{I}$ & T.I82-I9I7 & 94 & . & \\
\hline T.I52-IgI7 & . 109 & $\cdots$ & 45 & T.80-I9I8 & I4 & . & \\
\hline T.I53-I9I7 & . I IO & $\cdots$ & 46 & T.I48-I9I9 & 36 & . & \\
\hline T.I54-I9I7 & . III & $\cdots$ & 46 & т.787-Igrg & 77 & . & \\
\hline T.I55-I9I7 & . III & . & 46 & т.866-I9I9 & 38 & . & \\
\hline T.I56-I9I7 & . II 13 & . & 46 & T.867-I9I9 & 53 & . & \\
\hline T.I57-I9I7 & .. I24 & $\cdots$ & 49 & T.868-I9I9 & 59 & . & \\
\hline I.I58-I9I7 & .. I 35 & $\cdots$ & $5 \mathrm{I}$ & T.869-IgIg & 60 & . & \\
\hline T.I59-IgI7 & . I36 & . & $5^{\mathrm{I}}$ & T.942-I9I9 & .. 122 & . & \\
\hline T.I60-I9I7 & . I I 4 & . & 47 & T.943-I9I9 & .. I 37 & . & \\
\hline T.I6I-IgI7 & . 125 & . & 49 & T.944-I9I9 & .. 86 & . & \\
\hline T.I62-I9I7 & . III & . & 47 & T.945-I9I9 & .. 123 & . & \\
\hline T.I63-I9I7 & . I I 6 & . & 47 & T.946-IgIg & .. 129 & . & \\
\hline T.I64-I9I7 & . II7 & . & 47 & T.947-IgI9 & .. I 30 & . & \\
\hline T.I55-I9I7 & . II 8 & . & 48 & T.948-I9I9 & .. 106 & . & \\
\hline T.I66-I9I7 & 83 & . & 38 & T.250-I920 & .. 52 & . & \\
\hline T.I67-I9I7 & 120 & . & 48 & T.97-I92I & . III & . & \\
\hline T.I68-I9I7 & $9 I$ & . & $4 \mathrm{I}$ & I.II4-I92I & $5^{0}$ & . & \\
\hline T.I69-I9I7 & 98 & . & 43 & T.I7I-I92I & 63 & . & \\
\hline T.I70-IgI7 & 99 & . & 43 & T.I84-I92I & . . I39 & . & \\
\hline T.I7I-I9I7 & .. IOO & - & 43 & T.I86-I92I & $6 I$ & $\cdots$ & \\
\hline
\end{tabular}




\section{NUMERICAL INDEX II.}

\begin{tabular}{|c|c|c|c|c|c|c|c|c|c|}
\hline $\begin{array}{r}\text { Cata } \\
\mathrm{N}\end{array}$ & $\begin{array}{l}\text { logue } \\
\text { o. }\end{array}$ & $\begin{array}{c}\text { Registered } \\
\text { No. }\end{array}$ & & Page. & $\begin{array}{r}\text { Catal } \\
N\end{array}$ & $\begin{array}{l}\text { logue } \\
\text { o. }\end{array}$ & $\begin{array}{l}\text { Registered } \\
\text { No. }\end{array}$ & & Page \\
\hline I & . & $75 \mathrm{I}-\mathrm{I} 902$ & . & 8 & 40 & . T T. & T.290-I9I6 & . & 20 \\
\hline 2 & . & $44-1908$ & . & 8 & $4 I$ & . I I & I380-I900 & . & 20 \\
\hline 3 & . & I0I7-I905 & . & 8 & 42 & . & I98I-I899 & . & 20 \\
\hline 4 & . & $323-1872$ & . & 9 & 43 & . & I379-I900 & . & $2 I$ \\
\hline 5 & . & $804-1877$ & . & 9 & 44 & . & $1376-1900$ & . & $2 I$ \\
\hline 6 & . . & 368-I907 & $\ldots$ & 9 & 45 & . & I377-1900 & $\ldots$ & $2 I$ \\
\hline 7 & . . & 59I-I899 & . & 9 & 46 & . . & I378-I900 & . & $2 I$ \\
\hline 8 & . & $74 I-I 899$ & . & IO & 47 & $\therefore$ & $1372-1900$ & . & $2 I$ \\
\hline 9 & . . & T.2I4-IgII & $\ldots$ & IO & 48 & $\ldots$ & I982-I899 & $\ldots$ & $2 I$ \\
\hline IO & . & II3-I899 & .. & IO & 49 & . & $369-1907$ & . & 22 \\
\hline I I & . & $433-r 884$ & . & IO & 50 & $\ldots \mathrm{T}$ & T.II4-I92I & . & 22 \\
\hline I 2 & $\ldots \mathrm{T}$ & T.IOI-I9I 5 & . & II & $5 \mathrm{I}$ & . & T.76-I9I5 & . & 23 \\
\hline I 3 & . & T.20-I9I3 & . & II & 52 & $\ldots \mathrm{T}$ & T.250-I920 & . & 23 \\
\hline I4 & . . & T.80-I9I8 & . & II & 53 & & T.867-I9I9 & $\ldots$ & 23 \\
\hline I 5 & . & T.82-I9I3 & . & I2 & 54 & & 918-I904 & . & 23 \\
\hline I 6 & . . & T.83-I9I3 & . & I2 & 55 & . & I38I-I900 & . & 24 \\
\hline I7 & . . & $5 \mathrm{I} 6-\mathrm{I} 877$ & . & $\Upsilon 2$ & 56 & & I373-I900 & . & 24 \\
\hline I 8 & . & $480-I 894$ & . & I3 & 57 & & T.333-I9Io & . & 25 \\
\hline I9 & . . & $47-I 898$ & . & I3 & 58 & & T.7-I9I6 & . & 25 \\
\hline 20 & . . & $269-I 898$ & $\ldots$ & I3 & 59 & $\ldots \mathrm{T}$. & T.868-I9I9 & . & 25 \\
\hline $2 I$ & . & $742-1899$ & . & I4 & 60 & $\ldots \mathrm{T}$. & T.86g-IgIg & . & 26 \\
\hline 22 & . & $744-I 899$ & $\ldots$ & I4 & $6 I$ & & T. $186-1921$ & . & 27 \\
\hline 23 & . & 829-I902 & . & I4 & 62 & & $842-1907$ & . & 27 \\
\hline 24 & . . & I45-I907 & .. & I4 & 63 & & T.I7I-Ig2I & .. & 28 \\
\hline 2.5 & . & T.79-I9I2 & . & I5 & 64 & & 83 -Igor & $\ldots$ & 29 \\
\hline 26 & $\ldots I$ & T.29I-I9I6 & $\ldots$ & I5 & 65 & & T.42-19I7 & . & 29 \\
\hline 27 & .. & $469-1880$ & . & I5 & 66 & & $5+2-1872$ & . & 30 \\
\hline 28 & . . & $394-1878$ & . & I6 & 67 & & I04-I880 & $\ldots$ & $3 I$ \\
\hline 29 & . . & $288-I 886$ & . & I6 & 68 & & I379-I899 & . & $3 I$ \\
\hline 30 & . . & T.43-I9I7 & . & I6 & 69 & & $510-1899$ & . & $3 I$ \\
\hline $3 I$ & . & $289-I 886$ & . & I7 & 70 & & 5 II-I899 & . & 32 \\
\hline 32 & . & $497-I 905$ & . & I7 & $7 I$ & & I326-I87I & . & 32 \\
\hline 33 & . & T.II-IgOg & . & I8 & 72 & & II $8 I-I 903$ & . & 32 \\
\hline 34 & .. I & T.292-IgI6 & . & I8 & 73 & & $1182-1903$ & . & 33 \\
\hline 35 & . . I & I.273-I9I6 & . & I 8 & 74 & & 9I6-I907 & . & 33 \\
\hline 36 & $\ldots \mathrm{I}$ & T.I48-IgI9 & . & I9 & 75 & & T.25-I9I6 & . & 34 \\
\hline 37 & . & I979-I899 & . & I9 & 76 & & T.24-I9I6 & . & 35 \\
\hline 38 & . . I & T.866-IgI9 & $\cdots$ & I9 & 77 & . . T. & I.787-I9I9 & . & 35 \\
\hline 39 & - & $470-1880$ & . & I9 & 78 & .. T. & r.I95-I9I2 & . & 35 \\
\hline
\end{tabular}




\section{NUMERICAL INDEX II-cont.}

\begin{tabular}{|c|c|c|c|c|c|}
\hline $\begin{array}{c}\text { Catalogu } \\
\text { No. }\end{array}$ & $\begin{array}{l}\text { Registered } \\
\text { No. }\end{array}$ & Page. & $\begin{array}{c}\text { Catalogue } \\
\text { No. }\end{array}$ & $\begin{array}{c}\text { e Registered } \\
\text { No. }\end{array}$ & Page \\
\hline $79 \ldots$ & T.23-19I6 & 36 & IIO .. T & T.I53-I9I7 & 46 \\
\hline 80 & т. 26 -I9I 6 & 36 & I I I & T.I54-I9I7 & 46 \\
\hline $8 \mathrm{I}$ & T.I29-I909 & 37 & II 2 & T.I55-I9I7 & \\
\hline 82 & T.209-IgII & 38 & I I 3 & T.I56-I9I7 & 46 \\
\hline 83 & T.I66-I9I7 & 38 & I I 4 & T.I60-I9I7 & 47 \\
\hline 84 & $609-1884$ & 39 & II 5 & T.I62-I9I7 & \\
\hline 85 & T.I8I-I9I7 & 39 & II $6 \ldots$ & T.I63-I9I7 & 47 \\
\hline 86 & т.944-I9I9 & 39 & II $7 \ldots$ & T.I64-IgI7 & 47 \\
\hline 87 & T.I47-I9I7 & 39 & $118 \ldots$ & т.I65-I9I7 & \\
\hline 88 & T.I 50-I9I7 & 40 & II $\quad \ldots$ & T.97-I92I & 48 \\
\hline 89 & $792-1899$ & 40 & $120 \ldots \mathrm{T}$ & т.I67-I9I7 & 48 \\
\hline 90 & $79 \mathrm{I}-1899$ & 40 & $121 \ldots \mathrm{T}$ & T.176-I9I7 & \\
\hline 9I & Т.I68-I9I7 & $4 \mathrm{I}$ & $122 \ldots$ & T.942-I9I9 & 48 \\
\hline 92 & $240-I 89 I$ & $4 \mathrm{I}$ & $123 \ldots$ & Т.945-I9I9 & 49 \\
\hline 93 & $24 I-I 89 I$ & $4 \mathrm{I}$ & 124 & Т. I 57-I9I7 & \\
\hline 94 & T.I82-I9I7 & 42 & $125 \ldots \mathrm{I}$ & T.I $6 \mathrm{I}-\mathrm{rgr} 7$ & \\
\hline 95 & 476-I897 & 42 & $126 \ldots \mathrm{T}$ & т.I73-I9I7 & \\
\hline 96 & T.I 2 I-IgI & 42 & $127 \ldots$ & т.I77-I9I7 & \\
\hline 97 & $435-1893$ & 42 & 128 & т.I80-I9I7 & \\
\hline 98 & т.I69-I9I7 & 43 & $129 \ldots$ & т.946-rgro & \\
\hline 99 & т.I70-I9I7 & 43 & 130 .. & T.947-IgI9 & \\
\hline $100 \ldots$ & T.I7I-I9I7 & 43 & I3I $\ldots$. & T.I46-I9I7 & $5 c$ \\
\hline ror .. & T.I72-I9I7 & 44 & $132 \ldots$. & T.I48-IgI7 & $5^{1}$ \\
\hline ro2 & т.I74-I9I7 & 44 & I $33 \ldots$ T & т.I49-I9I7 & \\
\hline ro3 & т.I75-I9I7 & 44 & I $34 \ldots$ T & T.I5I-IgI7 & $5^{1}$ \\
\hline ro4 & Т.I78-I9I7 & 44 & $\mathrm{r} 35 \ldots \mathrm{T}$ & T.I58-IgI7 & \\
\hline ro5 & т.I79-I9I7 & 45 & $136 \ldots \mathrm{T}$ & T.I59-I9I7 & 5 \\
\hline 106 & T.948-I9I9 & 45 & I 37 & т.943-I919 & \\
\hline I07 & T.I44-I9I7 & 45 & I38 & $234-1869$ & \\
\hline ro8 & T.I45-I9I7 & 45 & $139 \ldots \mathrm{T}$ & T.I84-I92I & \\
\hline rog & T.I52-I9I7 & 45 & & & \\
\hline
\end{tabular}




\section{GENERAL INDEX.}

PAGE

Adam and Eve on samplers ..

Age, earliest record in

Museum collection of child's. .

Aguero, Dionisia Gomez de $\ldots \quad \ldots \quad \ldots 43$

Alonso, Josefa .. . . 39

Alphabets on samplers. . 4

Alsace, sampler from .. 33

Altars represented on samplers .. 28,29

American samplers .. 3 .

Amsterdam, Arms of City of

Antrobus, Mrs. (donor). . I8

Arias, Geferina . . . . 45

Bargagli, panel belonging to the Marchesa Eloisa

. . 34

Barnes, Amy .. $\quad$. . 2 I

Baxter, Miss (donor) . 36

Beach, Miss F. M.(donor)

Blackford, Hannah _. 22

Body, Mary Ann _. I8

Borders of samplers .. 7

"Boxers" on samplers 4

Brooks, mention of samplers by Thomas .. 2

Burgos, samplers from . . 40

Burrowes, Mary $\quad$. 9

Calera .. $\quad \ldots \quad$. . 40

Cann, Mary Ann . . 20

Casares, Theresa $\quad$. $3^{8}$

Castile and Leon, Arms of $\quad$. $\quad \ldots \quad \ldots 39$ 60
PAGE

Chapman, Mary _.. I5.

Copenhagen, sampler from .. $\quad . . \quad \ldots 53$

Costume on samplers .. 5

Countries producing samplers $\quad \ldots \quad \ldots \quad 3$

Creed, the Apostles' .. 7

Cridland, Elizabeth .. I6

Cross stitch $\quad$. $\quad \ldots \quad 6$

Cushion, Mrs. (donor) .. 22

Cut and drawn work .. 6

Cutler, Elisabeth $\quad$.. I5

Damask stitch . . 6

Danish samplers $\quad \ldots 5,53$

Darning stitches .. 6

De la Espada, Isabel Eulogia $\quad \ldots \quad \ldots 38$

Denmark, panel in $\mathrm{Mu}$ seum from $\quad . \quad \ldots 3$

Derivation of name sampler .. $\quad \ldots \quad \ldots$ I

Dixon, Miss A. L. (donor) Io

Documents, references in historical or legal $\ldots 2$

Dutch samplers $\quad \ldots 6,27$

Earliest dated sampler in Museum collection .. 3

Earliest record of child's age in Museum collection .. $\quad$. $\quad \ldots \quad 7$

Earliest record of worker's name in Museum collection

Earthenware, representation of contemporary 7

Edmands, Miss (donor) I6, I7 


\section{GENERAL INDEX-cont.}

PAGE

Edward VI's property, inventory of .. $\quad . .2$

Eeles, Esq., F. C. (donor) I2

Elizabeth of York, household accounts of, Queen

.. 2

Emblems of the Passion II, 28

English samplers 7-26

"Epistle" samplers .. 4

Erero, Dorothy . ${ }_{46}^{6}$

Erizarde, Ramona . 39

Eyelet stitch .. . . 6

Eyton, Miss (donor) I5, I9

Fadiez, Jose . . . . 49

Father," "This is my dear .. $\quad$.. $\quad$. 25

Fernandez, Petra .. 45

Fernandez, Teresa $\quad . \quad 50$

Fescue, meaning of .. 2

Fissch, Thomas. . . . 2

Florence, sampler from 36

Flowers on samplers .. 4

Foreign samplers .. 5

Forrer collection .. 3I

Fox and the crow, fable of the .. $\quad \ldots \quad \ldots 35$

French knots $\quad \ldots \quad \ldots .65$

French samplers 28, 29

Garcia, Rosa . . . . 47

Gardiner, Ann .. . . I8

German samplers 30-33

Göttlich, Maria . . 32

Grant, Miss (donor) .. I8

Grove, Mrs. (donor) 27, 53

Guzman, Dionisia . . 39

Guzman y Bergara, Maria De Lao $\quad$. $4 \mathrm{I}$

Harris, Esq., M.P., F. Leverton (donor) .. II

Harris, Jane .. ... Io

Hawkins, mention of samplers by William. . 2

Heath, Lucy ‥ ․ 23

Heraldry on samplers

Herrick, mention of 39 samplers by Robert .. 2 Hildburgh, F.S.A., Dr. W. L. (donor). . . 37

Holland, sampler from. . 27

Houses on samplers .. 4

Hulton, Jacobean panel in Museum worked by Mary .. $\quad . . \quad \ldots 3$

Human figures on samplers .. $\quad . . \quad \ldots \quad 4$

Hunt, Ann .. . . I7

Ingelbye, Anne _. II

Insignia of Spanish Kings 37

Italian influence on sampler patterns $\quad \ldots 3,7$

Italian samplers $\quad 34-36$

Johnson, mention of samplers by Dr. Samuel 2 Jones, Miss H. J. (donor) 24 Juano, Micaela Usebia 43

$\mathrm{Kyd}$, mention of samplers by Thomas .. I I

Lace scallops, embroidered copy of ..

Lace stitches, needlepoint $\quad 6$

Lançon in Provence .. 28

Landscapes on samplers 4

Lao Guzman y Bergara,

Maria De .. .. 4I

Lara, Maria de Jesûs Baleria $\quad \ldots \quad \ldots 40$

Laraona, Tiburcia de . 38

Leal, Anna Maria _. 42 


\section{GENERAL INDEX - cont.}

PAGE

PAGE

Leggatt, Mrs. (donor) .. I6

Lettering on samplers .. 6

Linstead, Charlotte . . 25

Linstead, Mrs. (donor) . . 25

Linstead, R. (donor) 23, 26

Literature, references in English .. I, 2

London Museum, sampler in the . . , sampler

Longhurst, Miss (donor) 25

Lopez, Florentyna .. 40

Lopez, Manuela _. 49

Lord's Prayer, the .. 7

Luchetti, Vittoria $\quad$. 35

Lucus(?), Margreet .. IO

Mackett, Elizabeth .. II

Map samplers .. $\quad \ldots 5,7$

Martinia, Raimunda . . 44

Materials used in working 5

May, Margreet

Mayne, mention of samplers by Jasper ... 2

Maxims on samplers .. 4

Methodism, influence of 4

Mexico, samplers from. . 37

Miller, Mrs. (donor) _. 9

Milles, mention of samplers by Thomas .. 2

Milton, mention of samplers by John

Montes, Nicola sa $\quad \ldots \quad 38$

Mor, Lorenza . . $\quad$.. 47

Moreno, Vicenta _. 48

Morland, sampler shown in picture by George. .

Names of workers

", , teachers

. .5, 37

Nicholls, Phebe. .. 19

Numerals on samplers. 4 Nuremburg, sampler from 32
Osmond, Mrs. (donor) . . 23

Palliser, Mrs. Bury (donor) 53

Paris, sampler from . . 29

Patterns on samplers .. 4

Pattern books, Venetian lace .. $\quad$. $\quad \ldots 44$

Perugia, samplers from $34-36$

Petit point . . . . 6

Pether, Mary _. $\quad$. 23

Piccolomini, Gullia . 35

Pickling, Catherine .. I7

Pittman, Hannah _. I2

Pluckrose, the late Miss I9

Pope, Rebeckah

Preston, Miss L. F. M. (donor)

Purpose of samplers, ori$\begin{array}{llll}\text { ginal .. } & \ldots & \ldots & \text { I }\end{array}$ Pynchebeck, Alys _. 3

Reeve, Mrs. Henry(donor) 32

Reticella. . . . . 6

Rhodes, Ann .. . . . I7

Robinson collection .. $3 \mathrm{I}$

Rocchi, Virginia $\quad$. 36

Sacred Trigram, the $28,31,36,39,53$

Saez, Maria del Pilar .. 47

Salamanca, Petra $\quad$. 48

Salter, Martha $\quad$. 8

$\begin{array}{llll}\text { Satin stitch } & \text {. } & \text {. } & 6\end{array}$

Scandinavian samplers. . 53

Sequence of samplers in Museum

\begin{tabular}{llr} 
Seville, sampler from & $\ldots$ & 3 \\
\hline
\end{tabular}

Shakespeare, mention of samplers by William . . I, 2 Sharman, M. . . . . I9 Shapes of samplers $\quad \ldots \quad 5$ Shorleyker, Richard .. 4 Sibmacher of Nuremburg, Hans .. . . . . 30 


\section{GENERAL INDEX—cont.}

Sidney, mention of samplers by Sir Philip .. I

Simmons, Ann .. . . 23

Ska, Uppland, Sweden, sampler from

.. 53

Skelton, mention of samplers by John. . . .

Smith, Maria _. 20,2I

Smith, Mary $\quad$. $\quad$.. I5

Smith, Matilda .. $\quad$.. 24

Smith, Susanna _. 2 I

Spanish Samplers 37-52

Starling, Sophia _. 22

Stern, Lady (donor) $\quad$. 38

Stitches on samplers .. 6

"Stump-work" . . 6

Swedish samplers $\quad 5,53$

"Tammy " cloth . 5

Taylor, Harriot. . . . 24

Texts on samplers, Scrip$\begin{array}{lllll}\text { tural } & . & \ldots & \ldots & 4\end{array}$

$\begin{array}{lllll}\text { Tiffany } & . . & \ldots & \ldots & 5\end{array}$

Tipper, Esq., Harry (donor) $\quad$.. $\quad \ldots$. I5

Toledo, samplers from .. 39

Tomson, Margaret .. 3

"Tönder " drawn work 5

Toroca y Edelhorn de San Matias, Luisa de. . 39

Tullett, Harriot
Tykell, apron in Museum worked by Mary . . 4

Verses on samplers, religious .. $\quad . . \quad \ldots \quad 4$

Vierlande, near Hamburg, samplers from the $\quad . \quad \ldots \quad 30,32$

Wakeling, Mary _. I6

Walker's collection of samplers, Dr. J. W... 34

Wallace Collection, picture in the $\quad . \quad$. $\quad 8$

Wallis, the late Henry. . 35

Wesley's hymns $\quad$. 4

Wheatley, R.A., sampler shown in picture by Francis .. $\quad$. 8

Wheeler, Martha _. I4

"White work" . . 6

Williamson, Rev. J. (donor) $\quad$.. . . I7

Wilson, T. Frederic (donor) $\quad$. $\quad$. . 29

Wood, Elizabeth $\quad$. 9

Wyman, Mrs. (donor) . . I7

Youngest workers, record in Museum collection $\begin{array}{lllll}\text { of } & \ldots & \ldots & \ldots & 7\end{array}$ 



\section{NOTICE.}

ThIs Catalogue may be obtained directly from the Victoria and Albert Museum, price $1 s .6 d$. net (by post $1 s$. $8 d$.). It may also be obtained either through any bookseller or directly from H.M. Stationery Office at the following addresses: Imperial House, Kingsway, London, W.C.2, and 28, Abingdon Street, S.W.1 ; 37. Peter Street, Manchester; I, St. Andrew's Crescent, Cardiff ; 23. Forth Street, Edinburgh; or from Eason \& Son, Ltd. 40 and $4 \mathrm{I}$, Lower Sackville Street, Dublin.

Among other publications of the Department of Textiles are :Publication No. Catalogues.

$72 \mathrm{~T}$ English Ecclesiastical Embroideries of the $\mathrm{I} 3^{\text {th }}$ to $\mathrm{I} 6 \mathrm{th}$ centuries. Second edition, with one illustration. pp. 45. Demy 8vo. 1911. 2d. [By post $\left.3 \frac{1}{2} d.\right]$

117 T Third edition, pp. viii and 47. 35 illustrations. Royal 8vo. 1916. 9d. [By post 1s.]

$118 \mathrm{~T} \quad$ Algerian Embroideries. pp. $14 ; 4$ plates. Royal 8vo. 1915. $4 d$. [By post $5 \frac{1}{2} d$.]

91 T Tapestries. By A. F. Kendrick. pp. 104; 19 plates. Crown 4 to. Paper boards. 1914. 1s. [By post 1s. 6d.]

$129 \mathrm{~T}$ Textiles from Burying Grounds in Egypt. By A. F. Kendrick. Vol. I., Græco-Roman period. pp. x. and 142 ; 32 plates. Crown 4to. 1920. 5s. [By post 5s. 6d.]. Cloth 6s. 6d. [By post 7s. 1d.] Vol. II in the press. Vol. III in preparation.

$141 \mathrm{~T}$ Franco-British Exhibition of Textiles. pp. 28 ; 18 plates. Crown 8vo. 1921. 9d. [By post $\left.10 \frac{1}{2} d.\right]$

\section{Guides.}

96 T Tapestries, Carpets and Furniture lent by the Earl of Dalkeith, March to May, 1914. pp. 27. Royal 8vo. 1d. [By post $\left.2 \frac{1}{2} d.\right]$

100 T The Bayeux Tapestry. pp. $34 ; 13$ plates. Royal 8 vo. Reprinted 1921. 1s. [By post 1s. 2d.]

$90 \mathrm{~T}$ English Costumes presented by Messrs. Harrods, Ltd. pp. iv and 20 ; 16 plates. Royal 8vo. 1913. 6d. [By post 8d.]

$111 \mathrm{~T}$ The Collection of Carpets. Second Edition. pp. viii and 88; 48 plates. Royal 8vo. 1920. 2s. 6d. [By post 2s. 10d.] Cloth 3s. $6 d$. [By post 3s. 11d.]

119 T Japanese Textiles. Part I.-Textile Fabrics. pp. xi and 68; 25 plates. Royal 8vo. 1919. 3s. 6d. [By post 3s. 9d.]

120 T Japanese Textiles. Part II.-Costume. pp. 65; 7 plates, 30 figs. Royal 8vo. 1920. 3s. 6d. [By post 3s. 9d.]

$136 \mathrm{~T}$ Notes on Carpet-Knotting and Weaving. pp. $26 ; 12$ plates. Crown 8vo. 1920. 9d. [By post $11 d$.]

144 T Chinese Embroideries. pp. $12 ; 8$ plates. Crown 8vo. 1921. $6 d$. [By post $\left.7 \frac{1}{2} d.\right]$

148 T Persian Woven Fabrics. [In preparation.] Portfolios.

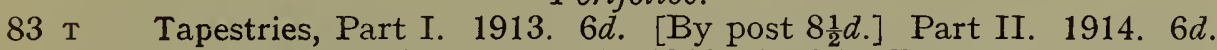
[By post $8 \frac{1}{2} d$.] Part III. 1916. 1s. $6 d$. [By post 1s. 9 $\left.\frac{1}{2} d.\right]$ In paper wrappers, $15 \times 12$.

Contents. Part I. (3 plates; in half-tone). (1) English, 17/18th centuries; (2) Flemish, c. 1500 ; (3) Brussels, 16th century. Part II. (3 plates; in collotype). English, 17th century. Part III. (9 plates; in collotype). Tapestry Maps, English, 16 th and 17 th centuries. Each plate has descriptive letterpress on the attached flysheet.

2 Coloured Reproductions of English Silk Embroidery of the early I 8 th Century, 1913. $1 \mathrm{~s}$. each plate. $15 \times 12$. [By post 1 s. $\left.2 \frac{1}{2} d.\right]$

Orders should be accompanied by a remittance (including postage). 

Plate I.



13. ENGLISH ; first half of 17 th century. (p II.) 
Plate II.
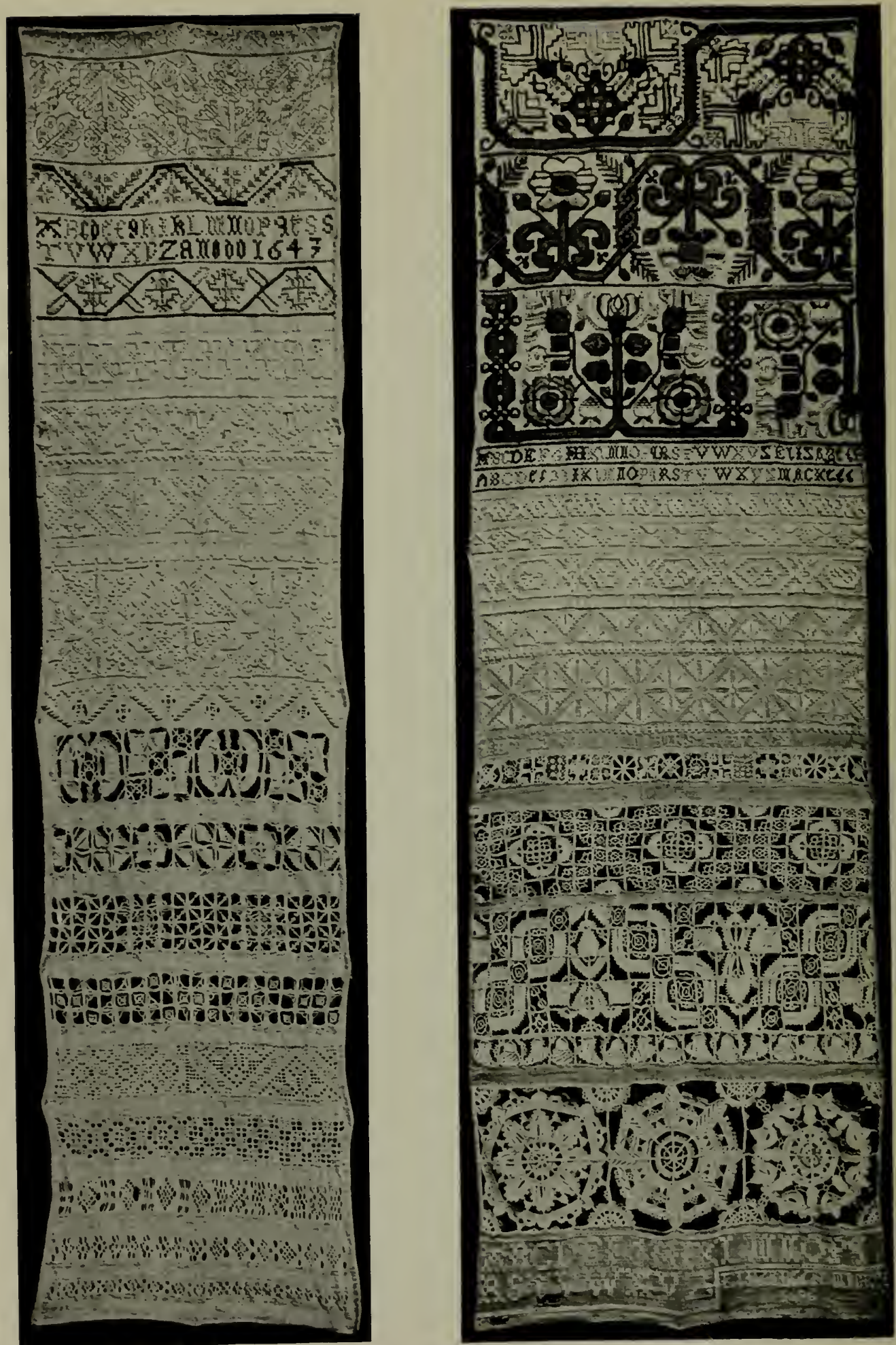

I and II. ENGLISH; dated I643 and I696. (pp. 8, Io.) 
Plate III.

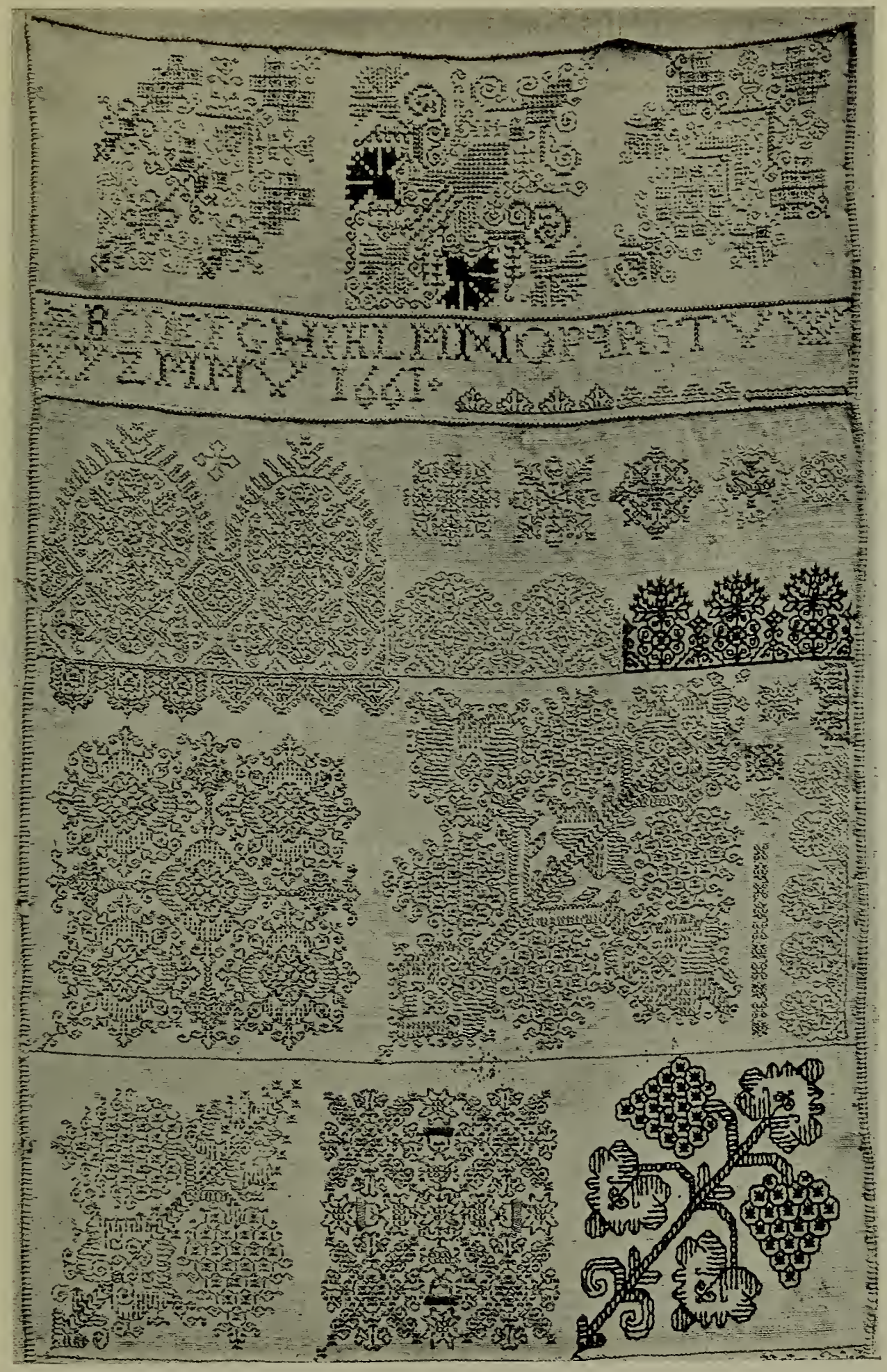

6. ENGLish : dated I66r. (p. 9.) 
Plate IV.

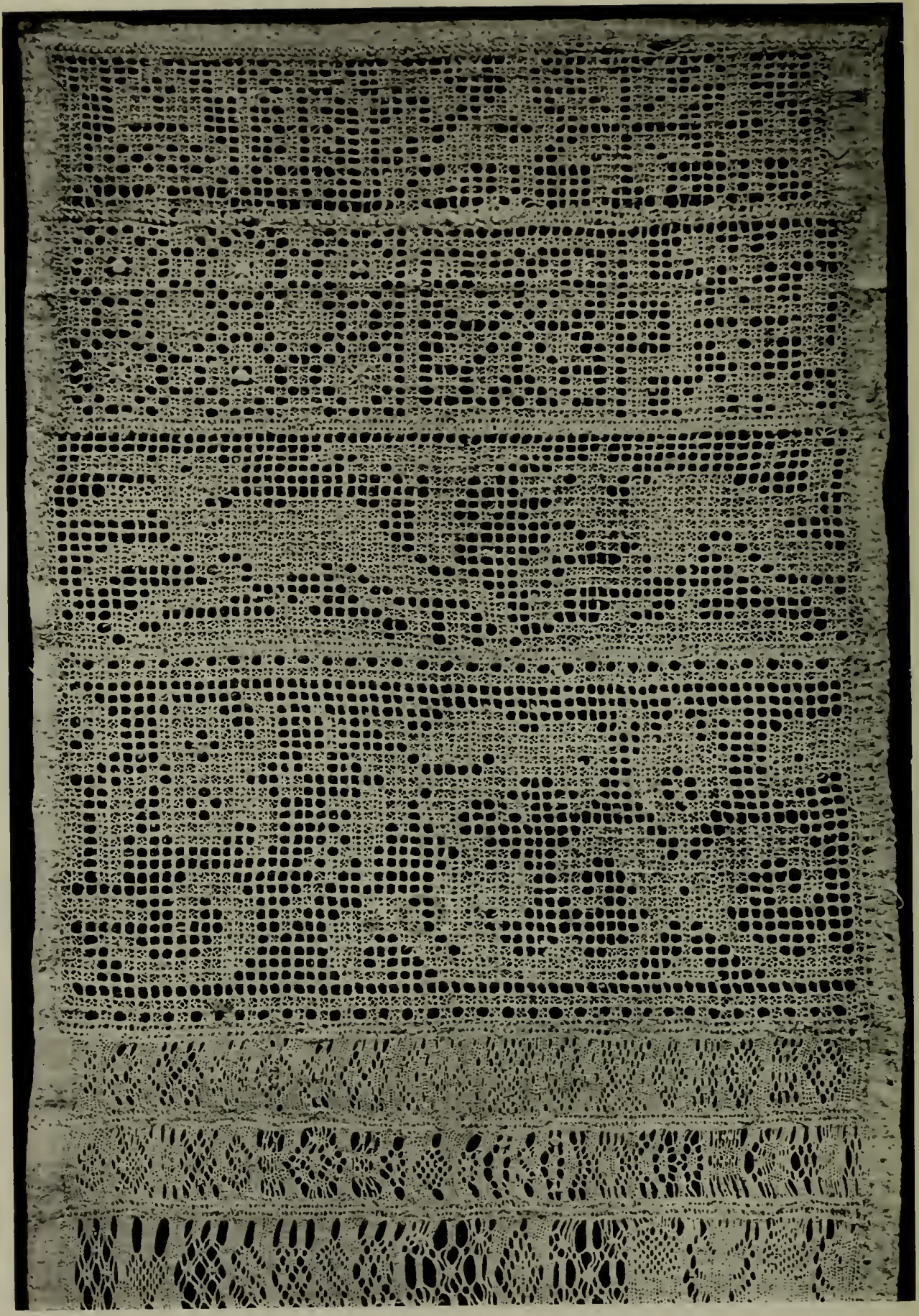

21. ExGLISH; second half of 17 th century. (p. I4.) 


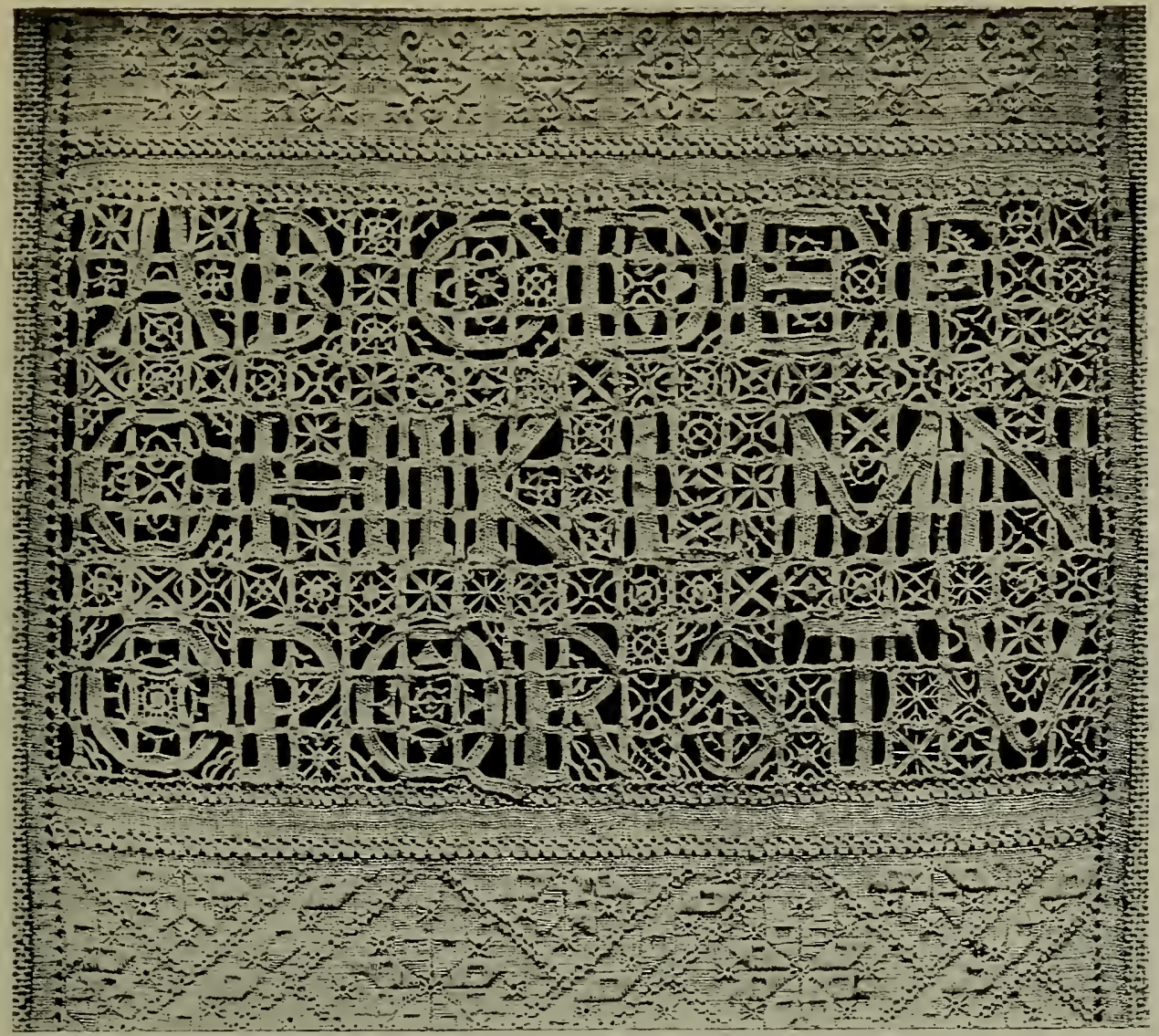

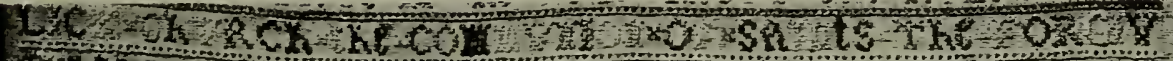

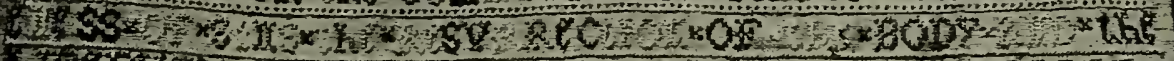

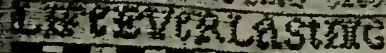

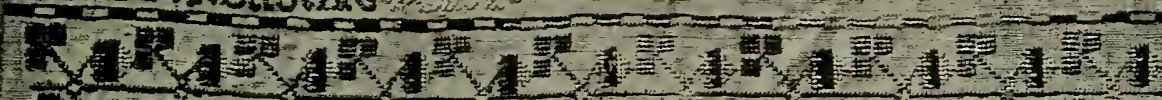

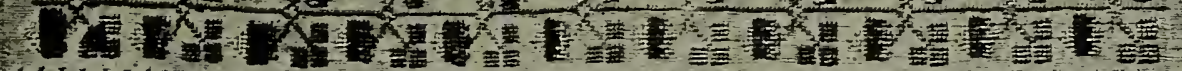

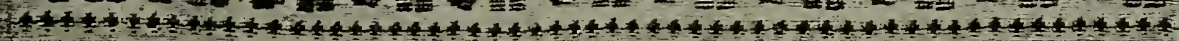

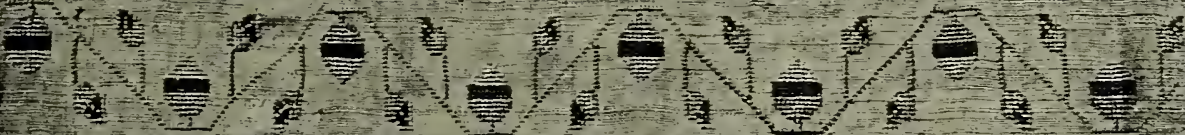

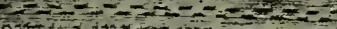

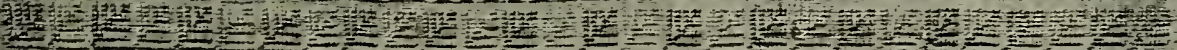

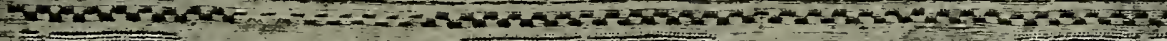

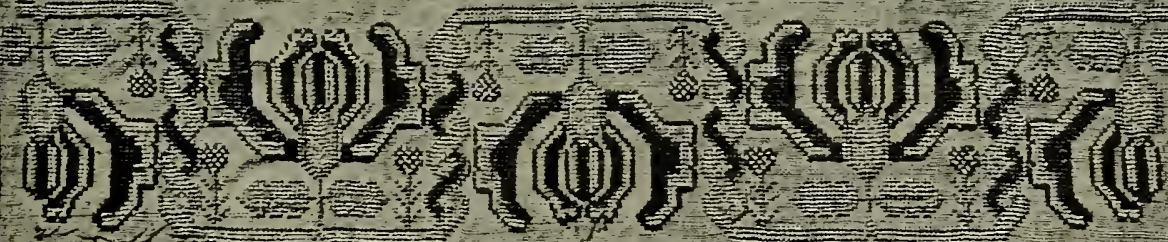

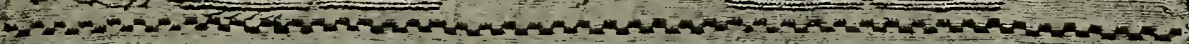

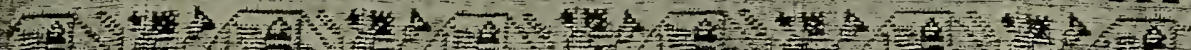

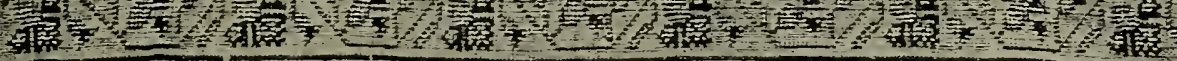

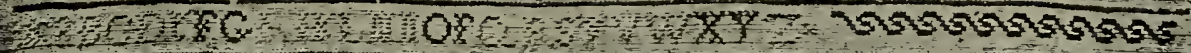

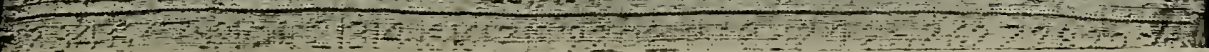

20. ExGLish; second half of I7th century. (p. 13.)

27. ENGLISH; dated I73I. (p. I5.) 
Plate VI.

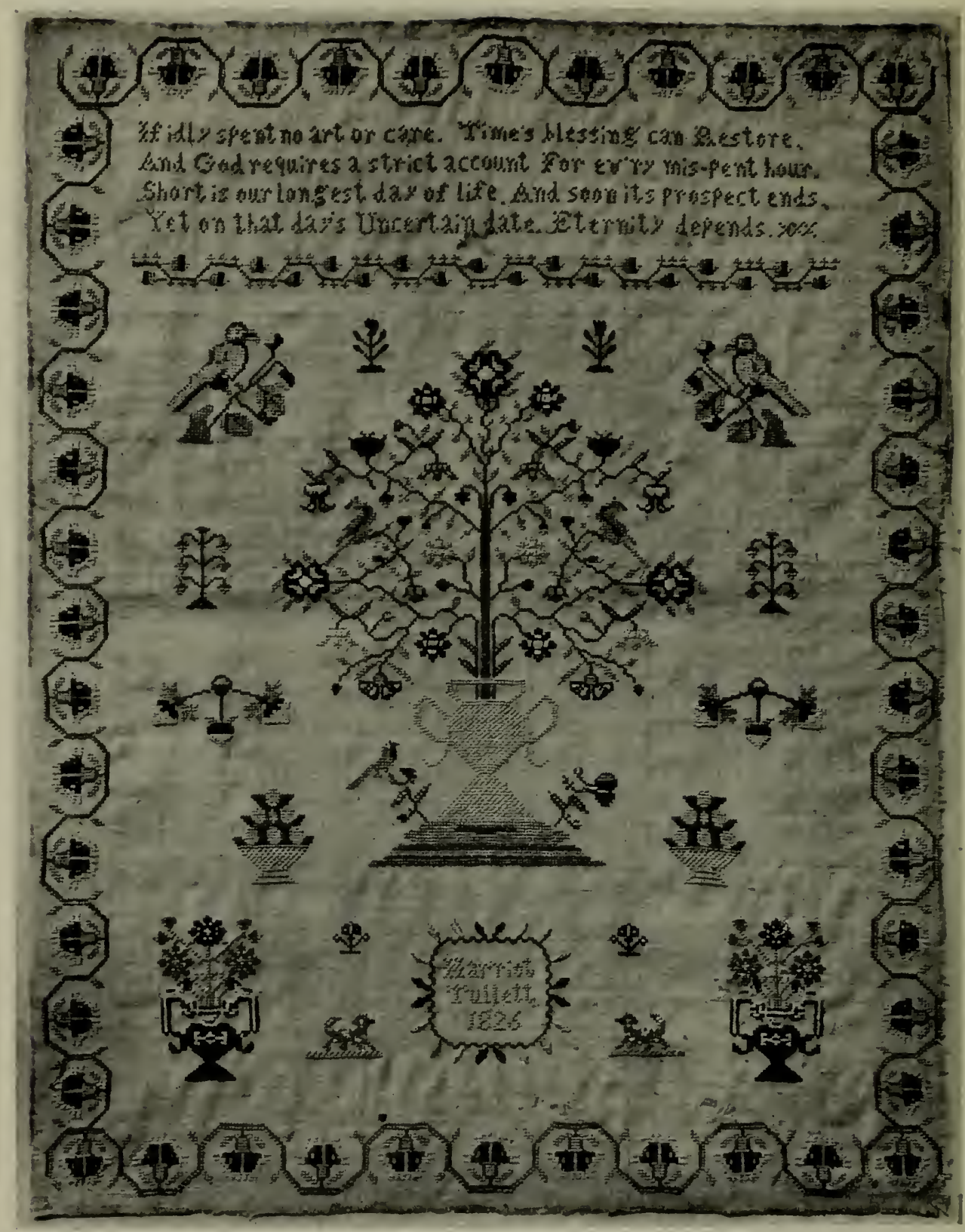

49. ENGLish; dated I826. (p. 22.) 
Plate VII.

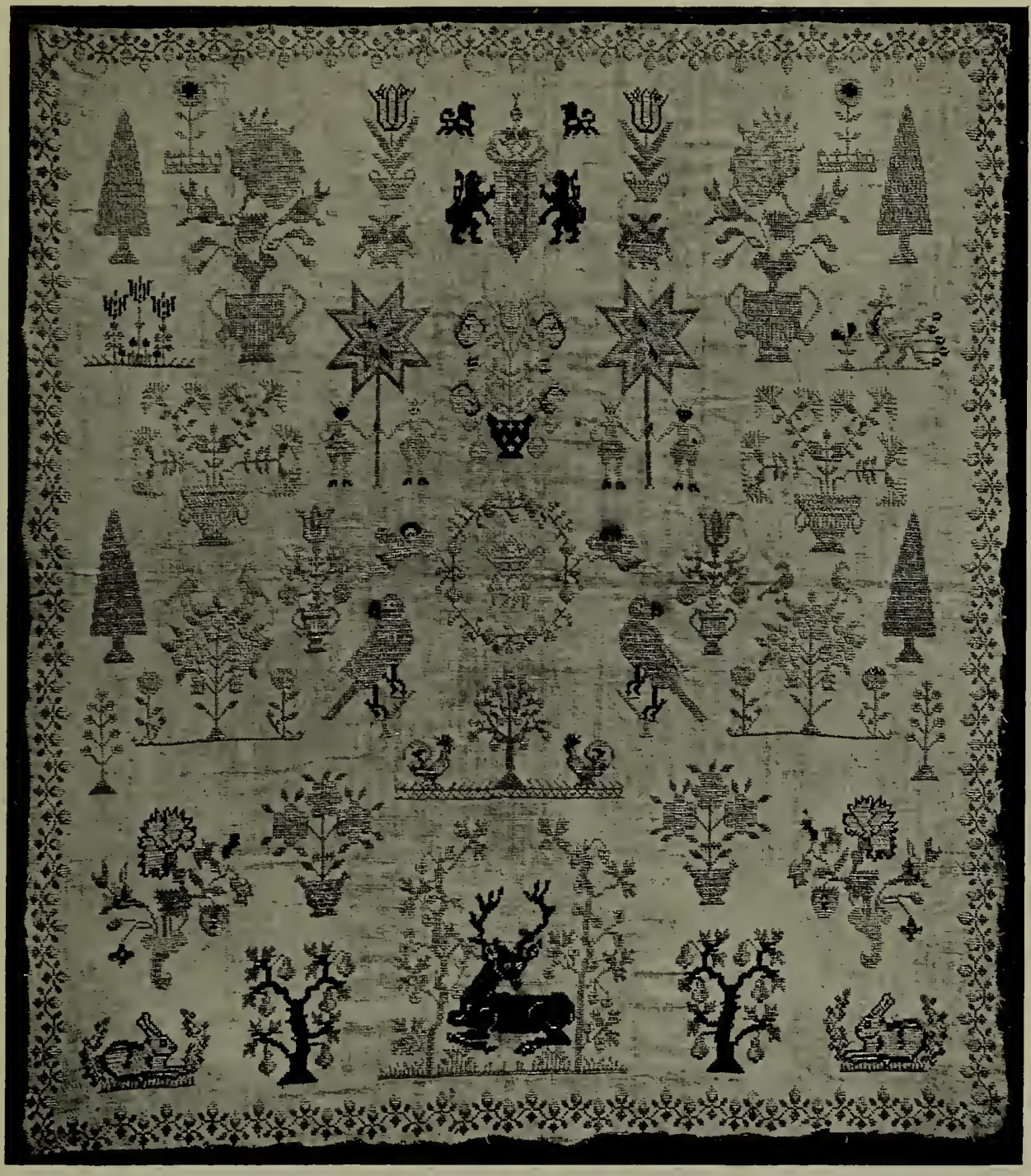

62. Dutch; dated i79S. (p. 27.) 
Plate VIII.

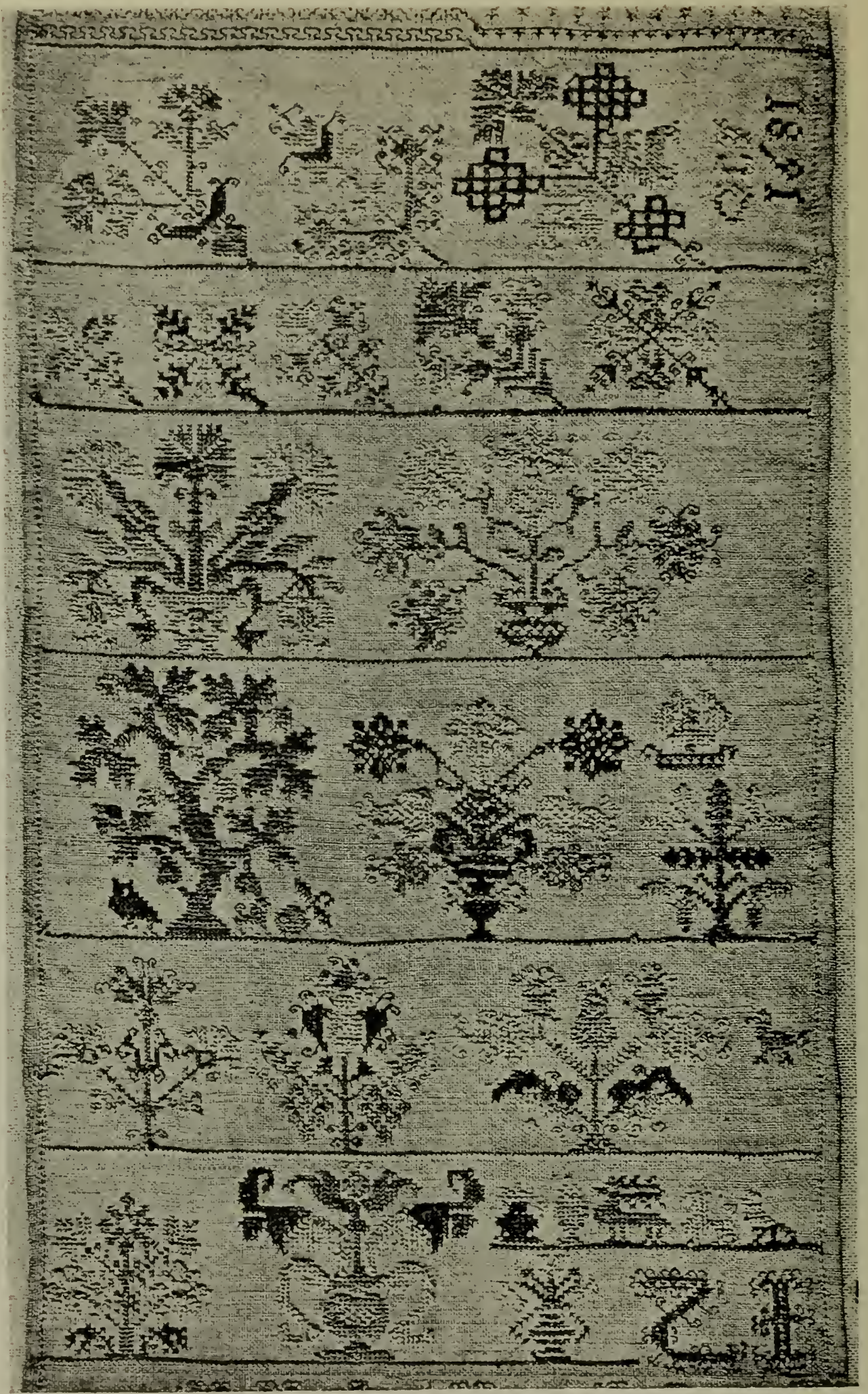

66. GERMAN; dated I68I. (p. 30.) 
Plate IX.

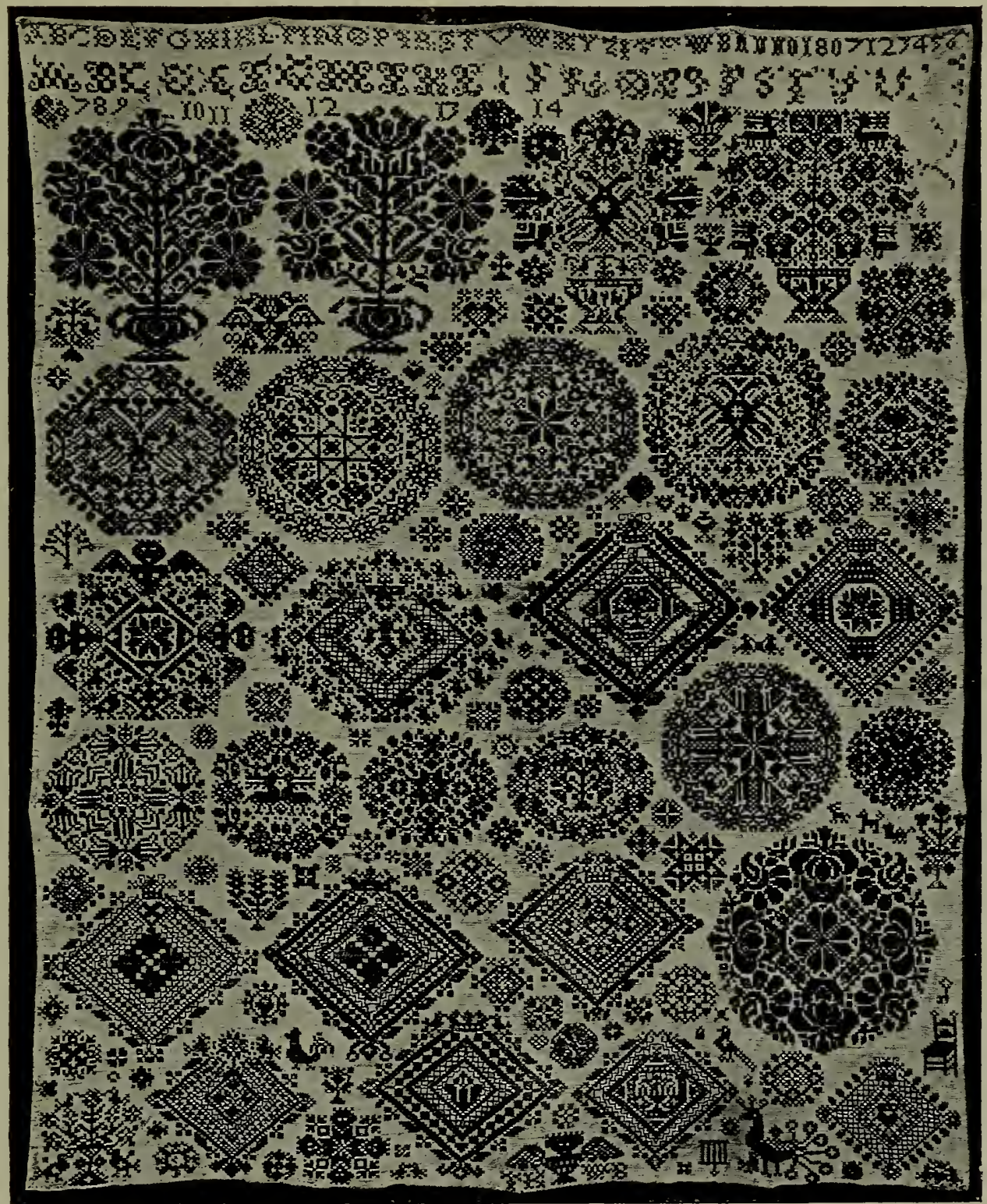

69. German; dated I807. (p. 3I.) 

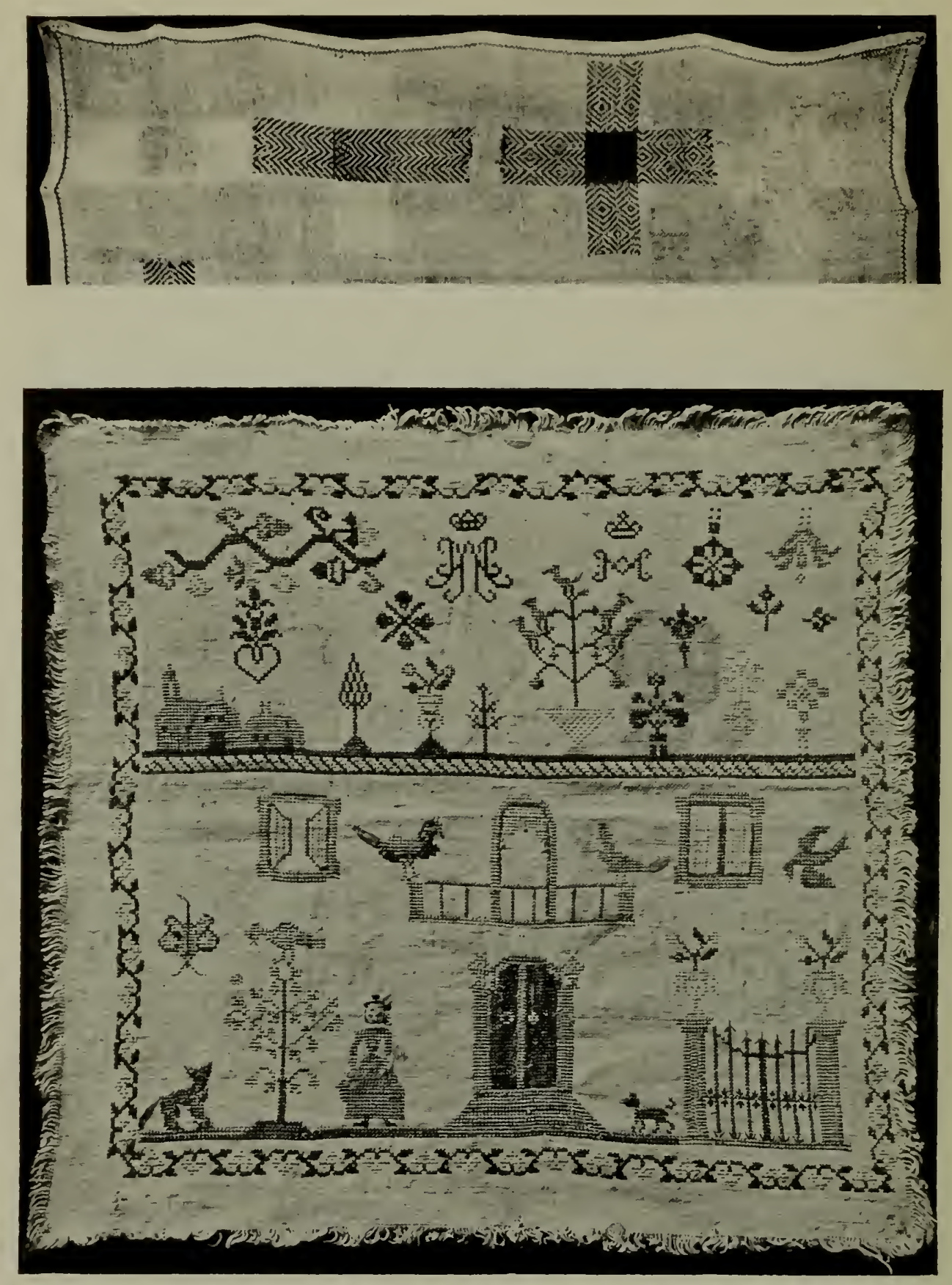

37. ENGLish OR DUtch; dated I799. (p. I9.)

78. From FioRENCE; late I8th or early Igth century. (p 35 ) 
Plate XI.

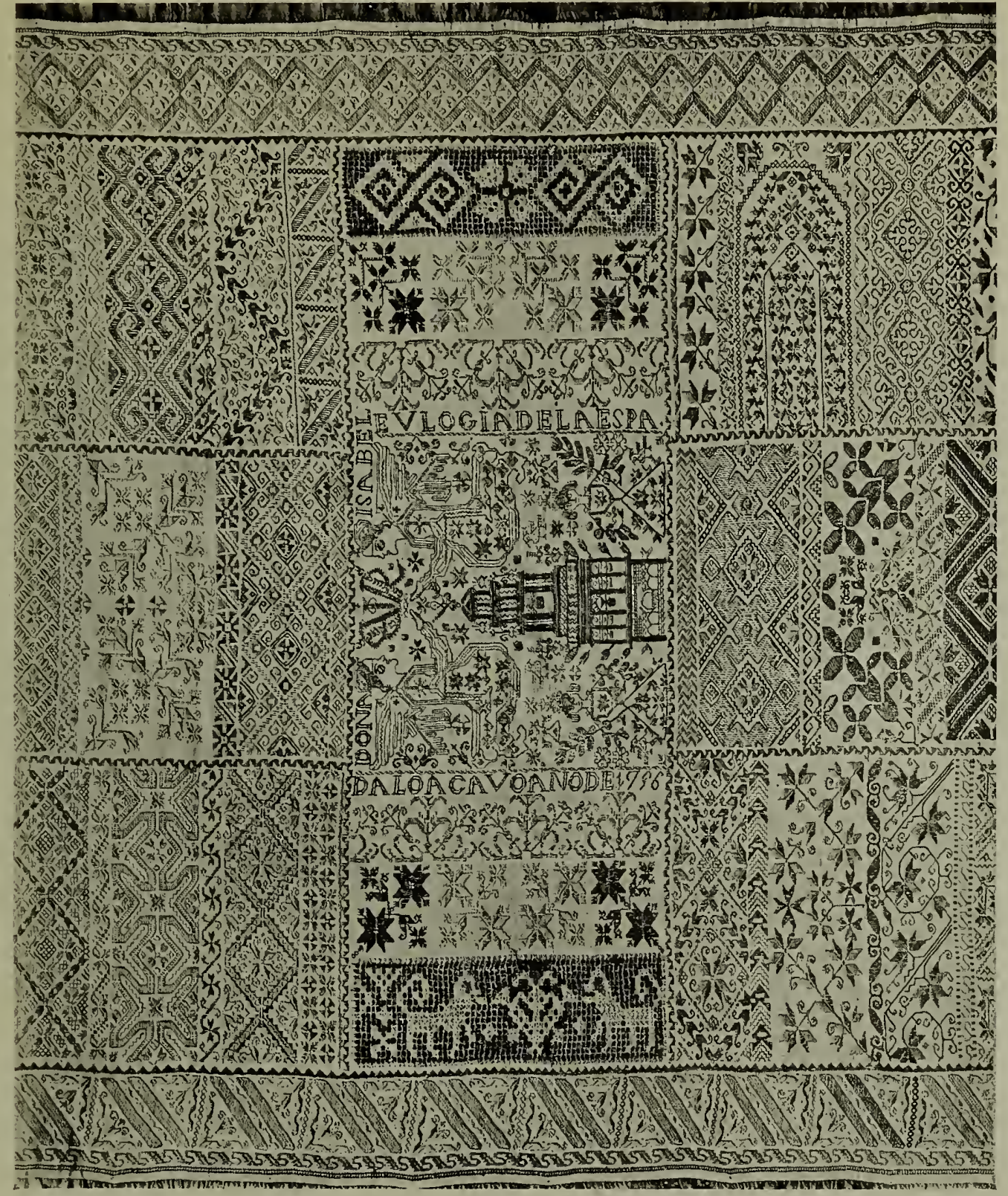

8I. SPANISH; dated I756. (p. 37 ) 


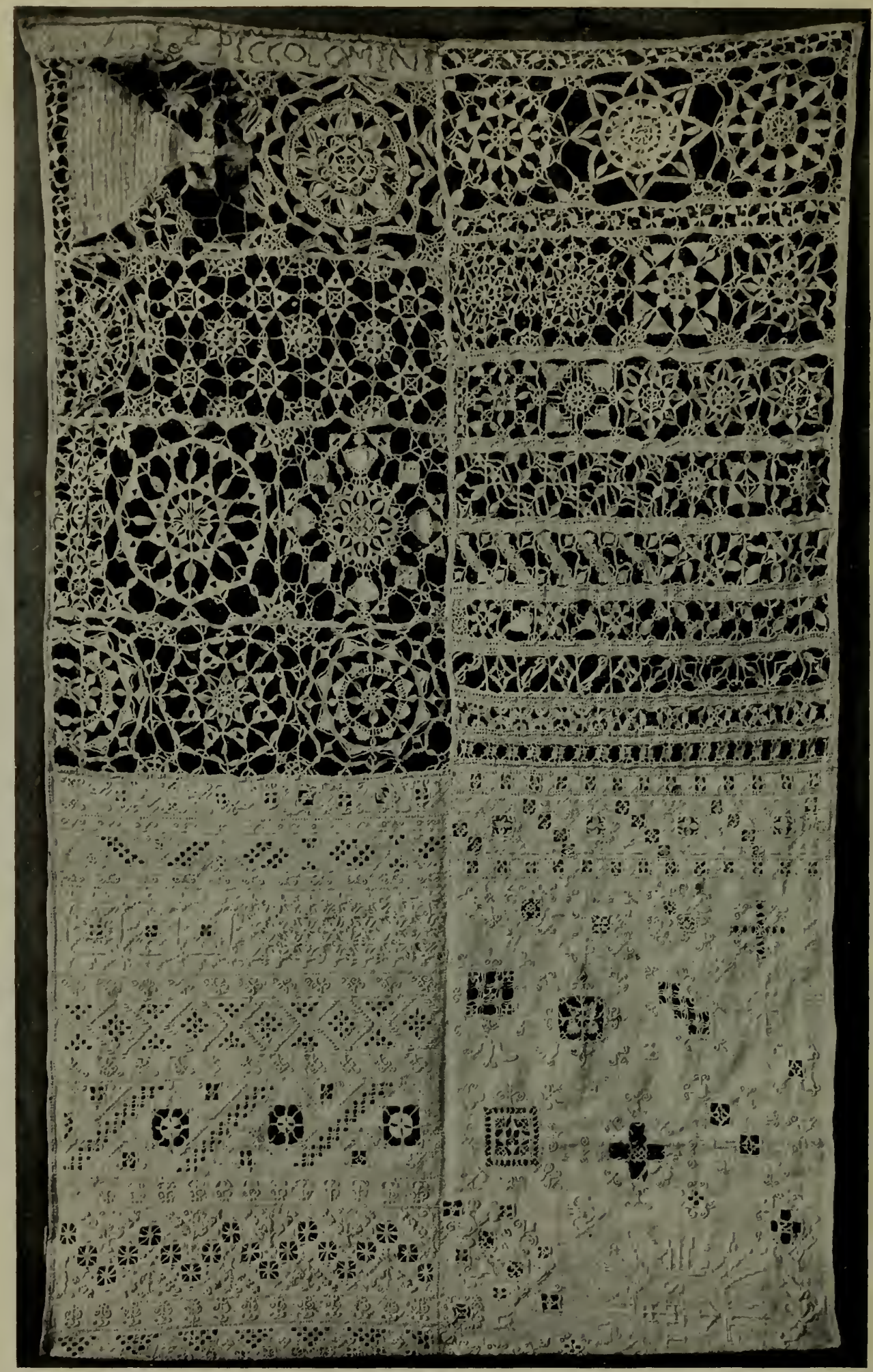

77. Italian; I7th century. (p. 35.) 



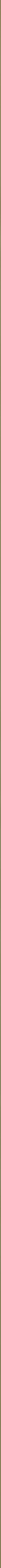


